\title{
生涯教育集会 歴代集会長一覧
}

\begin{tabular}{|c|c|c|c|c|c|c|c|c|c|}
\hline & 開催年度 & & 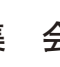 & 主 & & 開 催 & 日 & & 開催地 \\
\hline 第 1 回 & （1991 年度） & 紫 & 芝 & 良 & 昌 & H 3.11 .15 & $\sim$ & 16 & 前 \\
\hline 第 2 回 & （1992 年度） & 宮 & 井 & & 潔 & H 4. 10. 13 & $\sim$ & 14 & 京 \\
\hline 第 3 回 & （1993 年度） & 齊 & 藤 & 壽 & 一 & H 5. 10. 28 & $\sim$ & 29 & 弘 \\
\hline 第 4 回 & （1994 年度） & 松 & 倉 & & 茂 & Н 6.11 .17 & $\sim$ & 18 & 広 \\
\hline 第 5 回 & （1995 年度） & 下 & 田 & 新 & 一 & H 7.11 .1 & $\sim$ & 2 & 甲 府 \\
\hline 第 6 回 & （1996 年度） & 吉 & 村 & & 學 & H 8. 10. 11 & $\sim$ & 12 & 京 \\
\hline 第 7 回 & （1997 年度） & 吉 & 見 & 輝 & 也 & H 9. 5.31 & $\sim$ & 6.1 & 東 \\
\hline 第 8 回 & （1998 年度） & 江 & 藤 & 澄 & 哉 & H10. 6. 6 & $\sim$ & 7 & 福 \\
\hline 第 9 回 & （1999 年度） & 女 & 屋 & 敏 & 正 & H11. 5. 30 & $\sim$ & 31 & 横 \\
\hline
\end{tabular}

臨床内分泌代謝 Update 歴代会長一覧

\begin{tabular}{|c|c|c|c|c|c|c|c|c|c|c|c|}
\hline & 開催年度 & & & a & 長 & & & 催 & 日 & & 開催地 \\
\hline 第10回 & （1999年度） & & 高 & 原 & & 郎 & H12. & 3.17 & $\sim$ & 18 & 高 \\
\hline 第11回 & （2000年度） & 故 & 若 & 林 & 一 & 二 & H13. & 3.10 & $\sim$ & 11 & 東 \\
\hline & & 会長代行 & 寺 & 本 & & 明 & & & & & \\
\hline 第12回 & （2001年度） & & 青 & 木 & 矩 & 彦 & H14. & 3. 9 & $\sim$ & 10 & 大 \\
\hline 第13回 & （2002年度） & & 宮 & 地 & 幸 & 隆 & H15. & 3.15 & $\sim$ & 16 & 東 \\
\hline 第14回 & （2003年度） & & 玉 & 舎 & 輝 & 彦 & H16. & 3.13 & $\sim$ & 14 & 岐 \\
\hline 第15回 & （2004年度） & & 島 & 本 & 和 & 明 & H17. & 3.12 & $\sim$ & 13 & 札 \\
\hline 第16回 & （2005年度） & & 宮 & 森 & & 勇 & H18. & 3.25 & $\sim$ & 26 & 金 \\
\hline 第17回 & （2006年度） & & 高 & 野 & 加寿 & & H19. & 3.10 & $\sim$ & 11 & 東 \\
\hline 第18回 & （2007年度） & & 橋 & 本 & 浩 & 三 & $\mathrm{H} 20$. & 3.15 & $\sim$ & 16 & 高 \\
\hline 第19回 & （2008年度） & & 平 & 田 & 結喜 & & $\mathrm{H} 21$. & 3.13 & $\sim$ & 14 & 東 \\
\hline 第20回 & （2010年度） & 故 & 藤 & 枝 & 憲 & 二 & $\mathrm{H} 23$. & 1.28 & $\sim$ & 29 & 札 \\
\hline & & 会長代行 & 小 & 池 & 隆 & 夫 & & & & & \\
\hline 第21回 & （2011年度） & & 中 & 村 & 浩 & 淑 & $\mathrm{H} 24$. & 1.27 & $\sim$ & 28 & 浜 松 \\
\hline 第22回 & （2012年度） & & 片 & 山 & 茂 & 裕 & $\mathrm{H} 25$. & 1.18 & $\sim$ & 19 & 埼 \\
\hline 第23回 & （2013年度） & & 伊 & 藤 & 光 & 泰 & H26. & 1.24 & $\sim$ & 25 & 名古屋 \\
\hline 第24回 & （2014年度） & & 石 & 川 & 三 & 衛 & $\mathrm{H} 26$. & 11.28 & $\sim$ & 29 & 埼 \\
\hline
\end{tabular}




\title{
日本内分泌学会 臨床内分泌代謝 Update 受賞者一覧
}

\author{
若林賞 \\ 第12回 2001年度 石井 雄道（日本医科大学脳神経外科） \\ 第13回 2002年度 井上 勝 (岡山大学大学院医歯学総合研究科小児医科学) \\ 第14回 2003年度 吉岡 徹朗（京都大学医学研究科臨床病態医科学・内分泌代謝内科） \\ 第15回２004年度＼cjkstart福田いずみ（東京女子医科大学第二内科） \\ 第16回 2005年度 田辺 晶代（東京女子医科大学第二内科） \\ 第17回 2006年度 小野 昌美 (東京女子医科大学医学部第二内科) \\ 第18回 2007年度 大山 健一（虎の門病院内分泌センター間脳下垂体外科） \\ 第19回 2008年度 貴志 明生（滋賀医科大学内科学講座） \\ 第20回２010年度 \\ 第21回２011年度 \\ 深見 真紀 (国立成育医療研究センター分子内分泌研究部) \\ 高木 優樹（慶應義塾大学医学部小児科学教室）
}

\section{優秀演題賞}

第10回 1999年度

片上 秀喜 (宮崎医科大学第三内科)

橋本 年弘 (徳島大学医学部第一内科)

林和俊 (高知医科大学産科婦人科)

高橋 雅彦 (大阪大学大学院医学系研究科分子制御内科)

三井 理瑛 (京都大学大学院医学研究科臨床病態医科学)

大村 昌夫（横浜労災病院内科内分泌代謝科）

森田 浩之 (岐皁大学医学部総合診療部)

七里 眞義 (東京医科歯科大学第二内科)

第12回 2001年度 有田 和徳（広島大学医学部脳神経外科）

友田 昭二（大阪市立住友市民病院産婦人科）

関根 威 (虎の門病院脳神経外科)

太田寿 (医療法人神甲会隈病院総合検査部)

武田 嘉恵（東京医科歯科大学大学院体内分子制御学(内分泌・代謝内科)）

大村 昌夫（横浜市立大学医学部第三内科）

柴田 洋孝（慶應義塾大学保健管理センター）

田辺 晶代（東京女子医科大学第二内科）

本田 宗宏（帝京大学医学部附属溝口病院第四内科)

秋山 純子 (東京医科歯科大学大学院体内分子制御学(内分泌・代謝内科))

飯田 啓二（神戸大学大学院医学系研究科応用分子医学講座内分泌代謝・神経・血液腫瘍内科）

田中 督司（大阪赤十字病院内科）

太田一樹（長野県厚生連北信総合病院内科）

千勝 典子（日立総合病院内科）

山内 美香 (神戸大学大学院医学系研究科内分泌代謝・神経・血液腫瘍内科学)

第13回 2002年度 高野 達朗（横浜労災病院内分泌代謝内科）

高安 忍 (弘前大学医学部第三内科)

小口 純代（東京都立府中病院内科）

孫徹（神戸市立中央市民病院糖尿病内分泌内科）

鈴木 尚宜（東京大学医学部腎臟・内分泌内科）

山田 佳彦（横浜市立大学医学部第三内科）

竹野 亮子 (神戸大学大学院医学系研究科内分泌代謝・ 神経 ・ 血液腫瘍内科) 


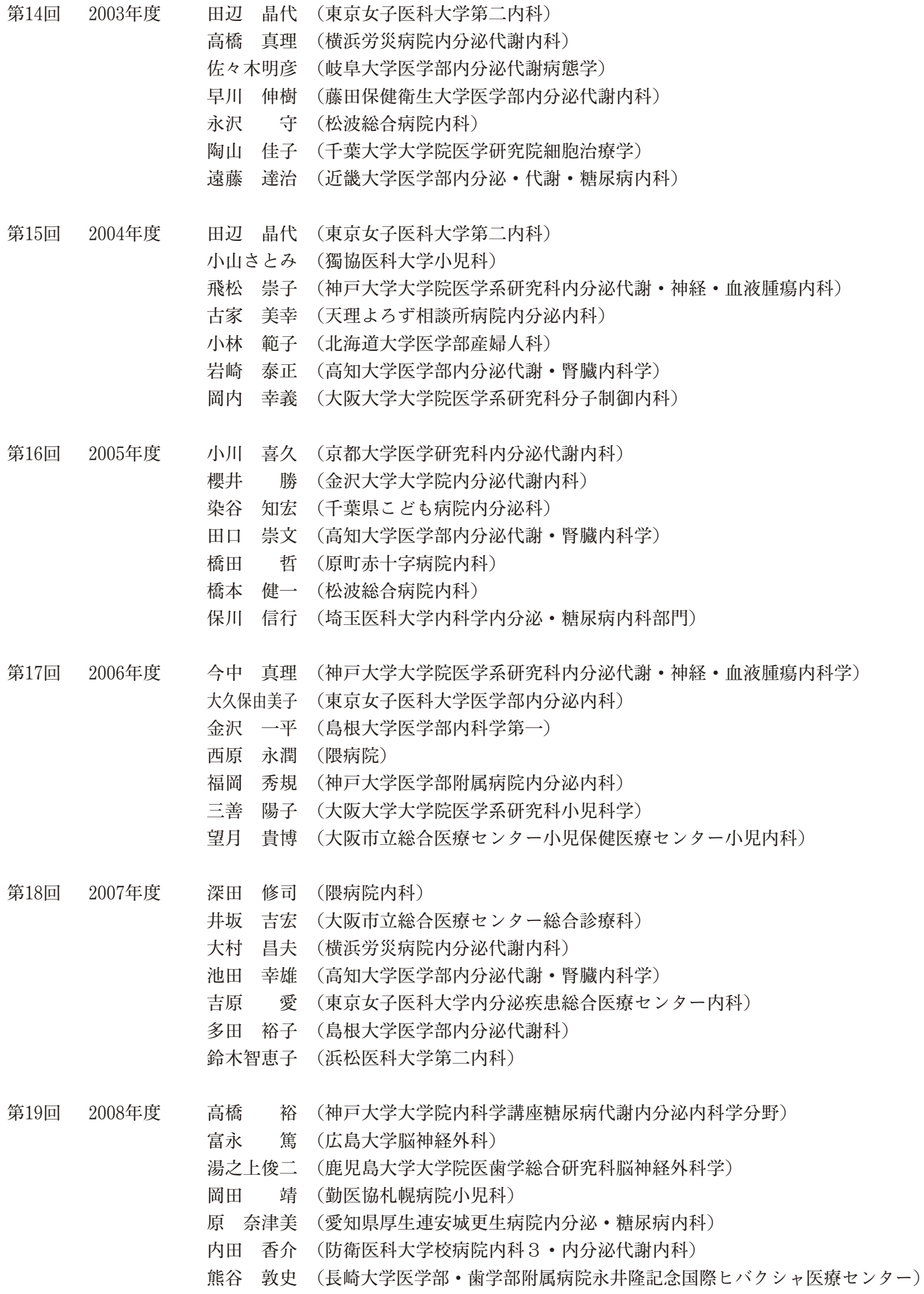


第20回 2010年度 三善 陽子（大阪大学大学院医学系研究科小児科学）

廣田 悠祐（千葉大学医学部附属病院糖尿病・代謝・内分泌内科）

杉山 雄大（国立国際医療研究センター病院糖尿病・代謝症候群診療部）

中村 明枝 (北海道大学医学部小児科)

和田 良春（財団法人田附興風会医学研究所北野病院糖尿病内分泌センター）

稲垣 兼一（岡山大学病院腎臓・内分泌・糖尿病内科）

田治 孔明（公立能登総合病院内科）

第21回 2011年度＼cjkstart廣田 圭昭（国立病院機構京都医療センター内分泌代謝科）

正司 真弓（千葉大学医学部附属病院糖尿病・代謝・内分泌内科）

櫻井 晃洋 (信州大学医学部遺伝医学・予防医学講座)

堀江 一郎 (国立病院機構佐賀病院内科)

湯野 暁子（京都医療センター内分泌代謝臨床研究センター）

佐久間一基（千葉大学大学院医学研究院細胞治療内科学講座）

優秀ポスター賞 第22回２012年度

坂東 弘教（神戸大学大学院医学研究科糖尿病・内分泌内科学）

永野 秀和 (千葉大学大学院医学研究院細胞治療内科学)

垣田真以子（国立病院機構京都医療センター内分泌代謝内科）

窪田 拓生（大阪大学大学院医学系研究科小児科学）

難波 多挙（国立病院機構京都医療センター内分泌・代謝内科）

第23回 2013年度 柴田 有亮（信州大学医学部付属病院糖尿病・内分泌代謝内科）

三井 俊賢 (慶應義塾大学医学部小児科)

中尾佳奈子（国立病院機構京都医療センター内分泌・代謝内科）

滝口朋子（千葉大学医学部附属病院糖尿病代謝内分泌内科）

鈴木佐和子（千葉大学医学部付属病院 糖尿病代謝内分泌内科) 


\section{第 24 回臨床内分泌代謝 Update 抄録集}

目次

会長挨拶 …………………………………………………………… 820

開催概要

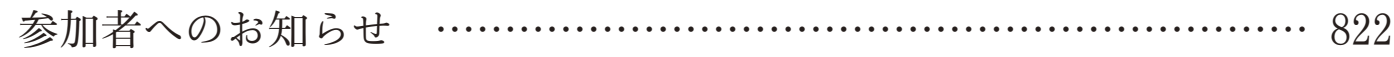

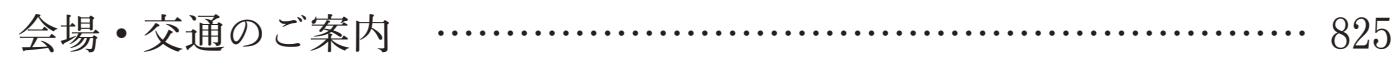

単位登録について ………………………….................. 828

プログラム

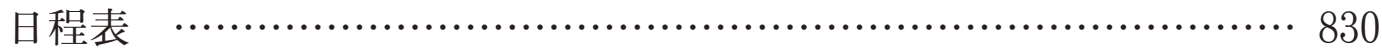

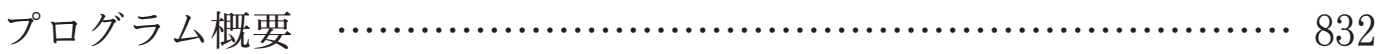

ポスターセッション一覧 ………………………………………… 838

ランチョン・イブニングセミナー一覧………………………..... 839

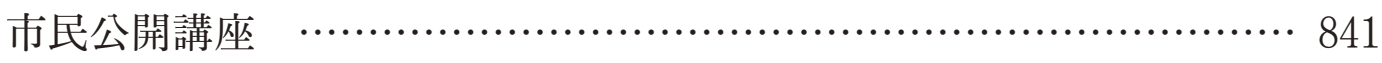

診断・治療に難渋した症例 …………………………………..... 842

優秀ポスター賞選考セッション ……………………………..... 844

ポスターセッション発表スケジュール …………………………..... 845 抄録集

Update

Meet the Expert ……............................................... 890

$\mathrm{ABC}$

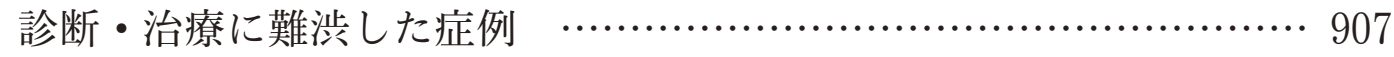

優秀ポスター賞候補演題 ………………………………… 911

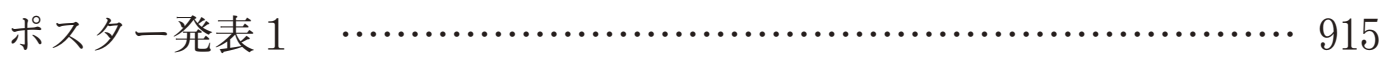

ポスター発表 2 …………………………………………........ 955

《お知らせ》

当誌はJ-STAGE https://www.jstage.jst.go.jp/browse/endocrine/-char/ja/に登載されます。 発行後一定期間は下記の認証が必要です。

購読者番号：JESmemberパスワード：endo2014 


\section{第 24 回 (2014 年) 臨床内分泌代謝 Update}

\section{プログラム委員}

麻生 好正

石橋 俊

市原 淳弘

加計 正文

草鹿 育代

竹内 靖博

東條 克能

林松彦

堀川 玲子

峯岸敬

山田 正信

山田 穂高
（獨協医科大学 内分泌代謝内科）

（自治医科大学 内科学講座内分泌代謝学部門）

（東京女子医科大学 高血压・内分泌内科）

（自治医科大学附属さいたま医療センター 総合診療科）

（自治医科大学附属さいたま医療センター 内分泌代謝科）

(虎の門病院 内分泌センター)

（東京慈恵会医科大学附属柏病院 糖尿病 - 代謝 - 内分泌内科)

(慶應義塾大学医学部 血液浄化・透析センター)

(独立行政法人国立成育医療研究センター 内分泌代謝科)

(群馬大学大学院医学系研究科 産科婦人科学)

(群馬大学 病態制御内科)

（自治医科大学附属さいたま医療センター 内分泌代謝科）

\section{査読委員}

\begin{tabular}{|c|c|}
\hline 尚史 & （和歌山県立医科大学 内科学第一講座） \\
\hline 好正 & （獨協医科大学内分泌代謝内科） \\
\hline 治 & （獨協医科大学病院小児科学教室） \\
\hline 寛 & (名古屋大学大学院医学系研究科 糖尿病 - 内分泌内科学) \\
\hline 卓也 & （埼玉医科大学内分泌・糖尿病内科） \\
\hline 俊 & （自治医科大学 内分泌代謝学部門） \\
\hline 理 & (埼玉医科大学＼cjkstart産科婦人科学） \\
\hline 淳弘 & （東京女子医科大学＼cjkstart高血圧・内分泌内科） \\
\hline 裕 & （慶應義塾大学医学部＼cjkstart腎臓内分泌代謝内科） \\
\hline 光泰 & (藤田保健衛生大学医学部 内分泌・代謝内科学) \\
\hline 暢也 & (京都大学大学院医学研究科 糖尿病 - 内分泌 - 栄養内科学) \\
\hline 敏彦 & （獨協医科大学越谷病院＼cjkstart糖尿病内分泌・血液内科） \\
\hline 常夫 & （愛知医科大学＼cjkstart乳腺・内分泌外科） \\
\hline 文男 & (岡山大学大学院 医歯薬学総合研究科総合内科学) \\
\hline 昌夫 & （横浜労災病院内分泌・糖尿病センター） \\
\hline 亮 & (帝京大学ちば総合医療センター 内科(内分泌代謝)) \\
\hline 弘 & (獨協医科大学越谷病院＼cjkstart泌尿器科） \\
\hline 正文 & （自治医科大学附属さいたま医療センター 総合診療科） \\
\hline 見貞行 & (聖マリアンナ大学横浜市西部病院 代謝・内分泌内科) \\
\hline 章 & （国立病院機構 京都医療センター 臨床研究センター） \\
\hline 仁 & (筑波大学医学医療系 内分泌代謝・糖尿病内科) \\
\hline 讨伊一郎 & (大阪大学大学院医学系研究科 内分泌・代謝内科学) \\
\hline 利嗣 & （島根大学医学部内科学講座内科学第一） \\
\hline 裕 & (神戸大学大学院医学研究科 糖尿病 - 内分泌内科学) \\
\hline 靖博 & （虎の門病院内分泌センター） \\
\hline & (東京医科歯科大学大学院医歯学総合研究科 細胞生理 \\
\hline
\end{tabular}




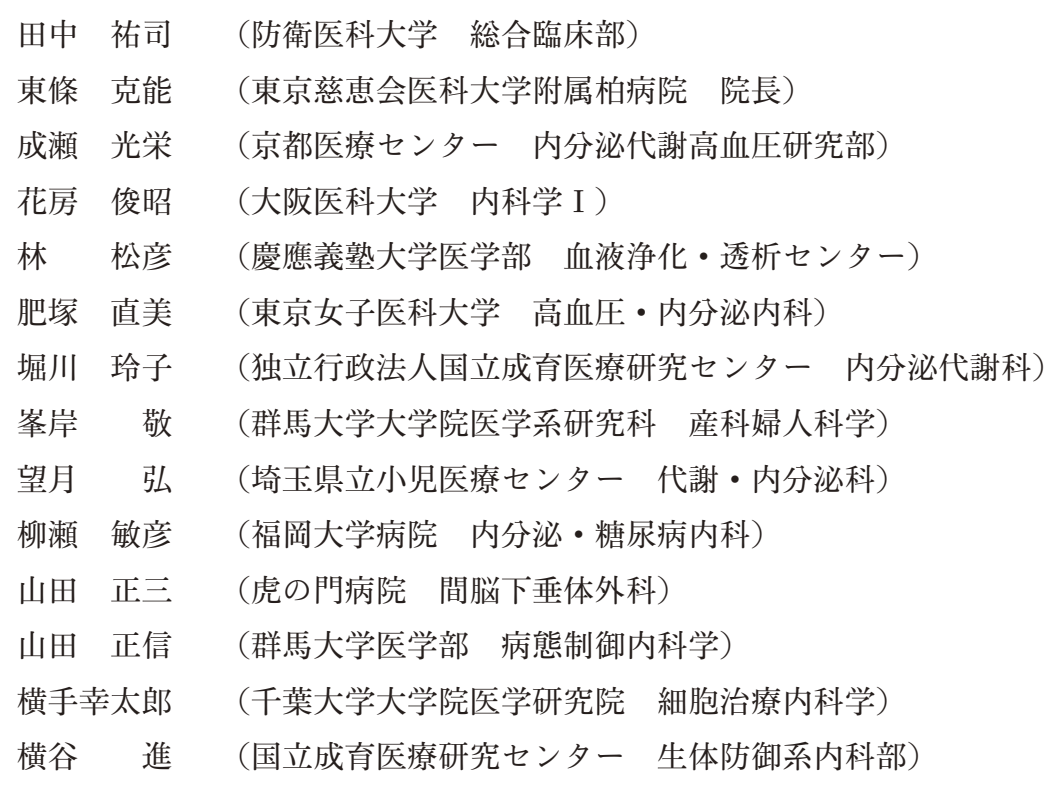

\section{優秀ポスター賞選考委員}

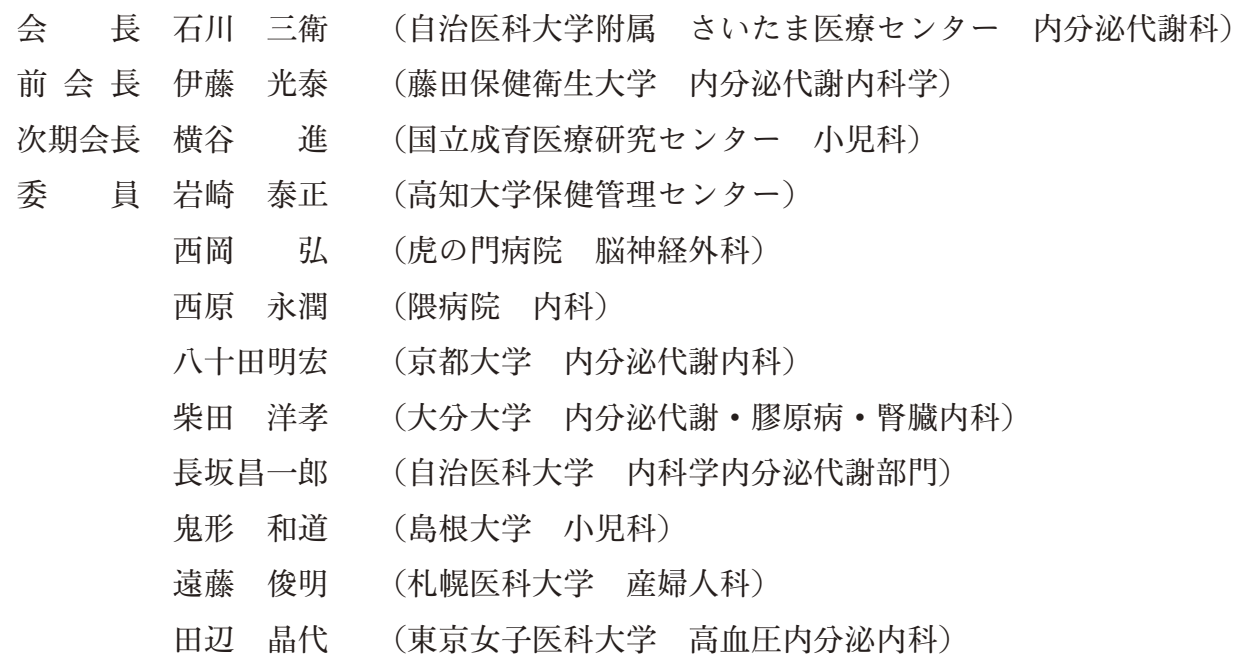


会長挨拶 


\section{会長挨拶}

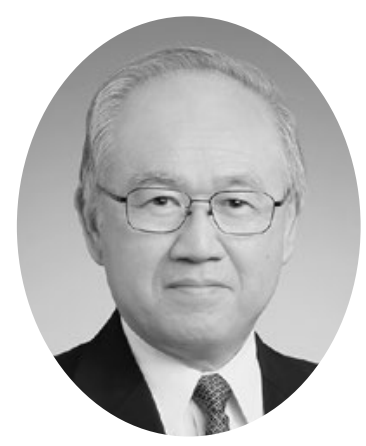

\section{第 24 回臨床内分泌代謝 Update の開催にあたって}

第 24 回 臨床内分泌代謝 Update

会長 石川 三 衛

自治医科大学附属さいたま医療センター内分泌代謝科教授

この度、日本内分泌学会の第 24 回臨床内分泌代謝 Update をお世話させていただくことになり大変光 栄に存じます。2014年11月28日(金)・29日(土)の 2 日間、さいたま市大宮ソニックシティで開催致します。

メインテーマは「Common diseases と内分泌学の接点」として、主会場では内分泌代謝疾患の最新の 診断と治療について、現在活躍されておられる先生方にご講演いただきます。まさにUpdate にふさし い演者の先生方に興味深い最新の話題を取り上げていただき、会員の先生方に有意義な情報を適切に抎 えし、臨床現場で応用していただきたいと考えています。第 2 会場は、専門医を目指す若い先生方や実地 臨床にお忙しい先生向けに入門コースとなる‥ABC セッション、Meet the Expert セッションを設けて 幅広い分野をカバーしていただくことができました。

一般演題は 319 題のご応募をいただきました。本学術集会が 11 月に繰り上げられて前回の第 23 回から 僅か10ヶ月後にもかかわらず多くの演題を発表して下さることに大変感謝しています。全演題はポス夕ー 発表となりますが、この中ですばらしい発表には優秀ポスター賞が授与されます。これは一般査読委員に より 40 題が選定され、さらに優秀ポスター賞選考委員の査読で 10 題に絞られます。第 2 日目に 10 題の 発表を行い、3-5 題の発表者に優秀ポスター賞が送られます。

本学術集会では、このように臨床内分泌代謝学の最新の進歩、基礎になる知識や手技の修得、Expert からの分かりやすい解説、各参加者のポスター発表など、各会員がそれぞれ静と動の両方の立場から参加 いただくことが最も重要な点です。知識を得、あるいは新たにして、日常臨床に活用してこそ本集会の意 義が見出されます。また、内分泌学会を中心に据えて common diseases に関連する境界領域の分野も包 含して解説いただけるよう配慮いたしました。

さいたま市は東京駅から僅か 25 分と利便性に優れ、首都圈内でも著しい発展を遂げる政令指定都市で す。市内には鉄道博物館、盆栽公園などの施設があり、学会を離れても楽しんでいただけるものと思いま す。実りある学術集会となるよう、多くの皆様のご参加、ご協力を心よりお願い申し上げます。

最後になりましたが、本学術集会の企画、開催にあたり、多くの皆様のご協力、ご支援をいただき誠に ありがとうございました。この場を借りて厚く御礼申し上げます。 
開 催 概 要 


\section{参加者へのお知らせ}

\section{I ．参加者の皆様へ}

1. 参加受付

(1) 日 時: 11 月 28 日(金) $8: 15 \sim 17: 30$

11 月 29 日(土) $8: 15 \sim 16: 30$

(2) 場 所：大宮ソニックシティ ホール棟 1 階 大ホール前

（3）参加費 : (現金のみの対応となります。おつりの無いように参加費をご用意願います。)

\begin{tabular}{|l|l|c|}
\hline \multirow{2}{*}{ 会員 } & 一般 & 12,000 円 \\
\cline { 2 - 3 } & 医療スタッフ・初期研修医 & 3,000 円 \\
\hline \multirow{4}{*}{ 非会員 } & 一般 & 13,000 円 \\
\cline { 2 - 3 } & 医療スタッフ・初期研修医 & 4,000 円 \\
\cline { 2 - 3 } & 医学部学生 & 無 料 \\
\hline
\end{tabular}

※参加費に抄録集代は含みません。

※医療スタッフ・初期研修医の方は本会ホームページにある証明書フォームに必要事項を記入して持参し

てください。

※医学部学生は、学生証をご提示ください。

※参加証は会場内では必ずお付けください。

2. クローク
(1) 日時: 11 月 28 日(金) $8: 15 \sim 19: 20$
11 月 29 日(土) $8: 15 \sim 17: 10$
(2) 場所：大宮ソニックシティ ホール棟 1 階 大ホール前

\section{3. 日本内分泌学会事務局受付}

大宮ソニックシティ ホール棟 1 階 大ホール前に設置します。

受付では新規会員登録、学会費納入、専門医単位登録、抄録集販売 $(2,000$ 円)を行います。

\section{4. 専門医単位登録について}

本会の参加により内分泌代謝専門医の更新研修単位 10 単位が取得できます。資格をお持ちの方は、受付にて 「認定更新研修単位登録票」をご提出ください。会期前ないし終了後の提出、代理の方の提出は出来ませんので、 ご注意ください。

\section{5. 託児所}

託児所の利用をご希望される方は、本会ホームページをご参照ください。

6. ランチョンセミナー・イブニングセミナー

ランチョンセミナーでは扔弁当を、イブニングセミナーでは軽食をご用意いたしますが、数に限りがございま す。予めご了承ください。なお、整理券の配布はいたしませんので、直接会場にお越しください。 


\section{II. 演者の方へ}

\section{1. 口演発表}

(1) 受付場所

大宮ソニックシティ ホール棟 1 階 大ホール前

(2) 受付日時

11 月 28 日(金) $8: 15 \sim 17: 30$

11 月 29 日(土) $8: 15 \sim 16: 30$

※発表の 30 分前までに PC 受付にてご自身の発表デー夕の確認ならびにご提出を打願いいたします。 ※お預かりしたデー夕は終了後、責任を持って消去いたします。

(3) 講演方法

演台上の操作パッドを各自で操作し、発表してください $(\mathrm{PC}$ 本体は、演台上にはありません)。 各会場には、Windows 7 + Power Point 2013、2010、2007をインストールしたPCをご準備しております。

(4) デー夕持込について(Windows は本体持込かデー夕、Macintosh は本体持込のみとさせて頂きます。)

•Windows の場合

Power Point 2013、2010、2007 で作成したデータをUSB メモリに保存し、PC 受付にお持込ください。 また、動画データを使用の場合は、Windows Media Player で再生可能であるものに限定いたします。 講演で他のデータ(静止画、動画、グラフ等)をリンクさせている場合は、必ず元のデータも保存してい ただき、事前に PC 受付にて動作確認をしてください。

- Macintosh の場合

各自の PC で講演していただきます。事前に PC 受付にて動作確認を行ってください。モニタ一端子は MiniD-sub 15 ピン 3 列コネクター(通常のモニター端子)です。必要な場合は、専用の接続ケーブルも 必ずご持参ください。

※ PC を抒持込の場合は、PC 受付にて確認終了後、PC をご自身で会場内の $\mathrm{PC}$ オペレーター席までお持 ちください。

※ビデオ、スライド、DVDでの発表はできません。

(5) その他

・発表時間は座長の指示に従ってください。時間厳守でお願いいたします。

・診断・治療に難渋した症例のプレゼンテーションは6 分以内でお願いします。

・優秀ポスター賞候補口演のプレゼンテーションは 7 分以内でお願いします。

2. ポスターセッション

一般演題は、すべてポスター発表で行います。

（1）会場：〈第 1 ポスター会場〉大宮ソニックシティビル 地下 1 階 第 1 展示場

〈第 2 ポスター会場〉大宮ソニックシティビル 4 階 市民ホール $403 ・ 404$

※それぞれの会場前にポスター受付を設けます。揭示用のピンとリボンをお受け取りください。

(2) 発表者は、セッション開始5 分前までにご自身のポスターの前で待機してください。

(3) 発表時間：発表 3 分、討論 3 分、計 6 分です。時間厳守にてお願い致します。

(4) スケジュール(貼付・発表・撤去時間)

11 月 28 日 (金)

11 月 29 日(土)

$\begin{array}{lrrr}\text { 貼付時間 } & 9: 00 \sim 10: 00 & \text { 貼付時間 } & 9: 00 \sim 10: 00 \\ \text { 発表時間 } & 13: 15 \sim 14: 45 & \text { 発表時間 } & 13: 15 \sim 14: 45 \\ \text { 撤去時間 } & 17: 30 \sim 18: 15 & \text { 撤去時間 } & 16: 30 \sim 17: 15\end{array}$

※ポスターは1日間の掲示です。

※撤去時間を過ぎても貼られているポスターは、事務局で撤去(処分)いたします。 
(5) ポスターパネル

1 題につきタテ $180 \mathrm{~cm} \times \exists コ 90 \mathrm{~cm}$ (演題番号、演題名のスペースを含む)です。

パネル左肩に $20 \mathrm{~cm} \times 20 \mathrm{~cm}$ の演題番号を事務局で用意します。

演題名、演者名、所属等は $20 \mathrm{~cm} \times 70 \mathrm{~cm}$ のスペースをご利用下さい。
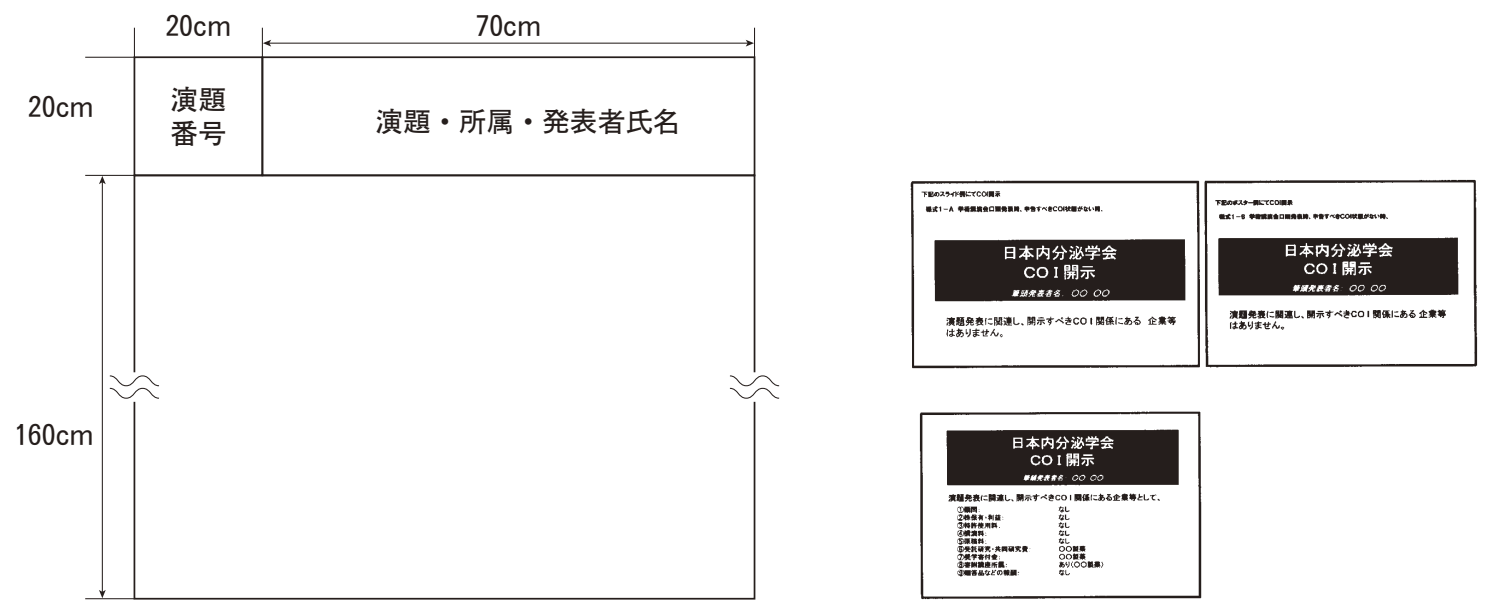

【COI(利益相反) 自己申告書】

日本内分泌学会では、口演またはポスター発表をされる方は、利益相反の申告が必要です。

日本内分泌学会の利益相反の開示に関する詳細は学会ホームページにてご確認ください。

「開示スライド例」をダウンロードまたは同様式を作成し、スライドの 1 枚目またはポスターの最後にご呈 示くださいますようお願いいたします。

III. 座長・コメンテーターの方へ

口演セッションの座長・コメンテーターの方は、セッション開始 10 分前までに、口演会場の前方右手にある「次 座長席」にお越しください。

ポスターセッションの座長は、各ポスター会場前のポスター受付にお越しください。

時間厳守にて進行をお願いします。

\section{IV，表彰式・閉会式}

11 月 29 日(土) 17 時 00 分より第 1 会場(大ホール)で優秀ポスター賞の表彰式ならびに閉会式を行います。 受賞者(期間中に会場に掲示されます)は原則としてご参加ください。不在の場合は、代理の方の出席をお願いします。

\section{V．トラベルグラントの申請について}

ポスター 研修医・学生部門の発表者の方は、トラベルグラントが申請できます。ホームページから必要書類(申 請書・所属長の証明書)をダウンロードしていただき、11月 28 日(金) 15 時以降にトラベルグラント受付(大ホール 前)にて、ご本人が申請ください。代理申請は認められません。 


\section{交通のご案内}

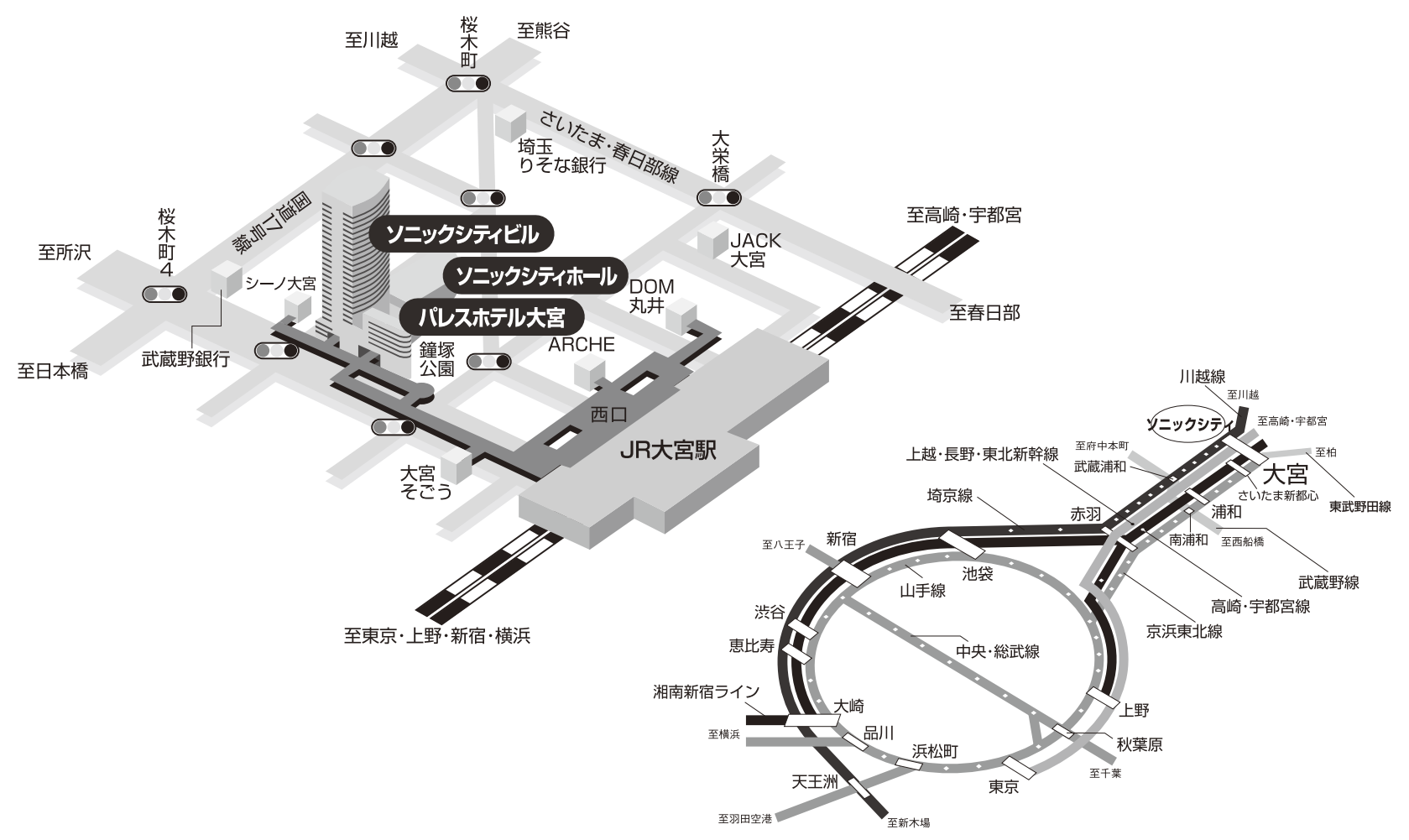

》川》新幹線で

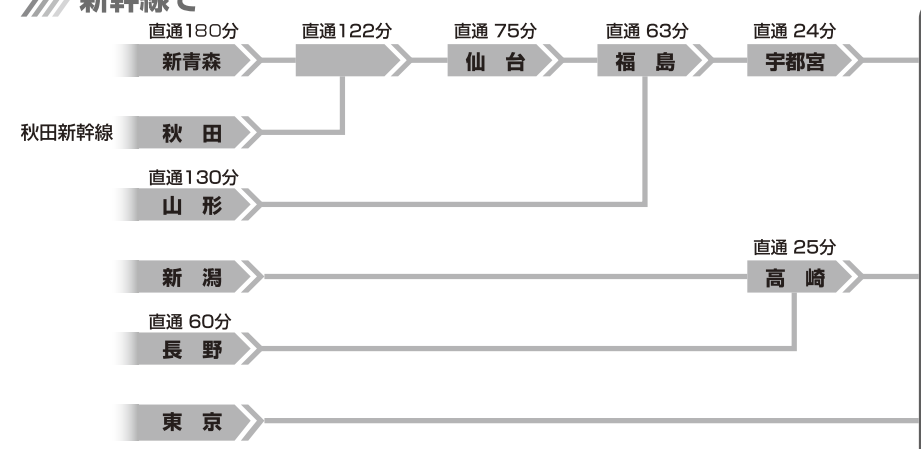

11) 在来線で

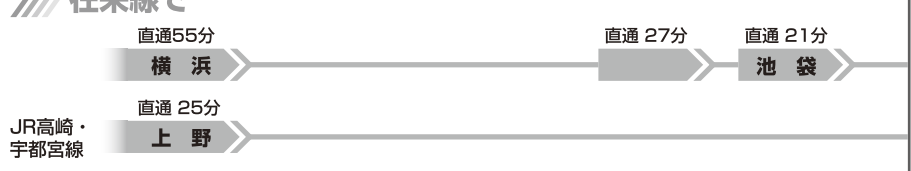

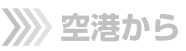

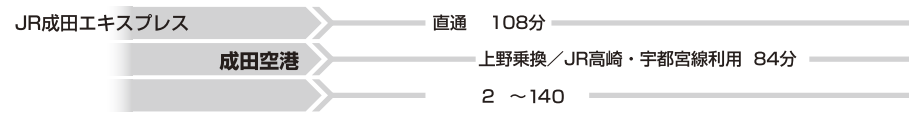

モノレール

浜松町乗換 $/ J R$ 京浜東北線利用 64 分

5

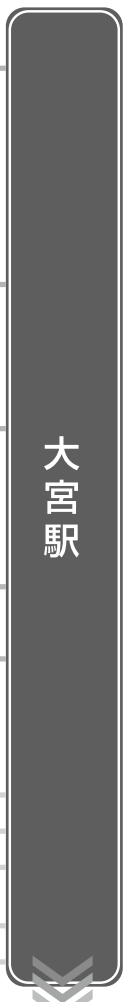

お車でお越しの場合 首都高速道路埼玉大宮線[新都心西 $\mid C]$ より $1 \mathrm{~km}$

駐車場 ソニックシティ地下駐車場……30分/200円 利用時間/7:00 23:00

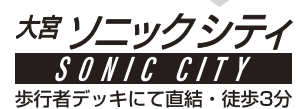

大宮ソニックシティ

テ330-8669 埼玉県さいたま市大宮区桜木町 1-7-5

TEL:048-647-4111 http://www.sonic-city.or.jp/ 


\section{会場のご案内}

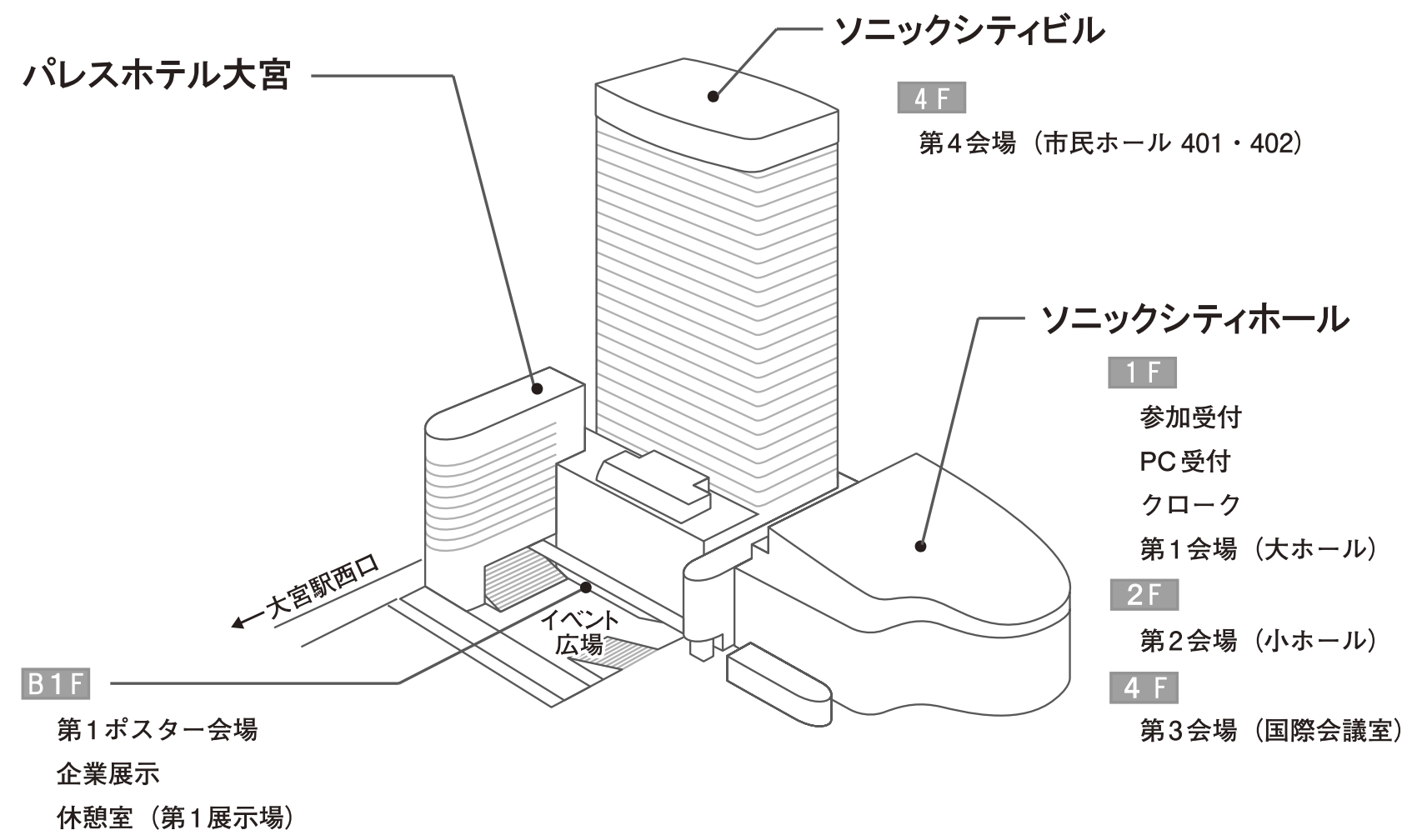

\section{B1F}

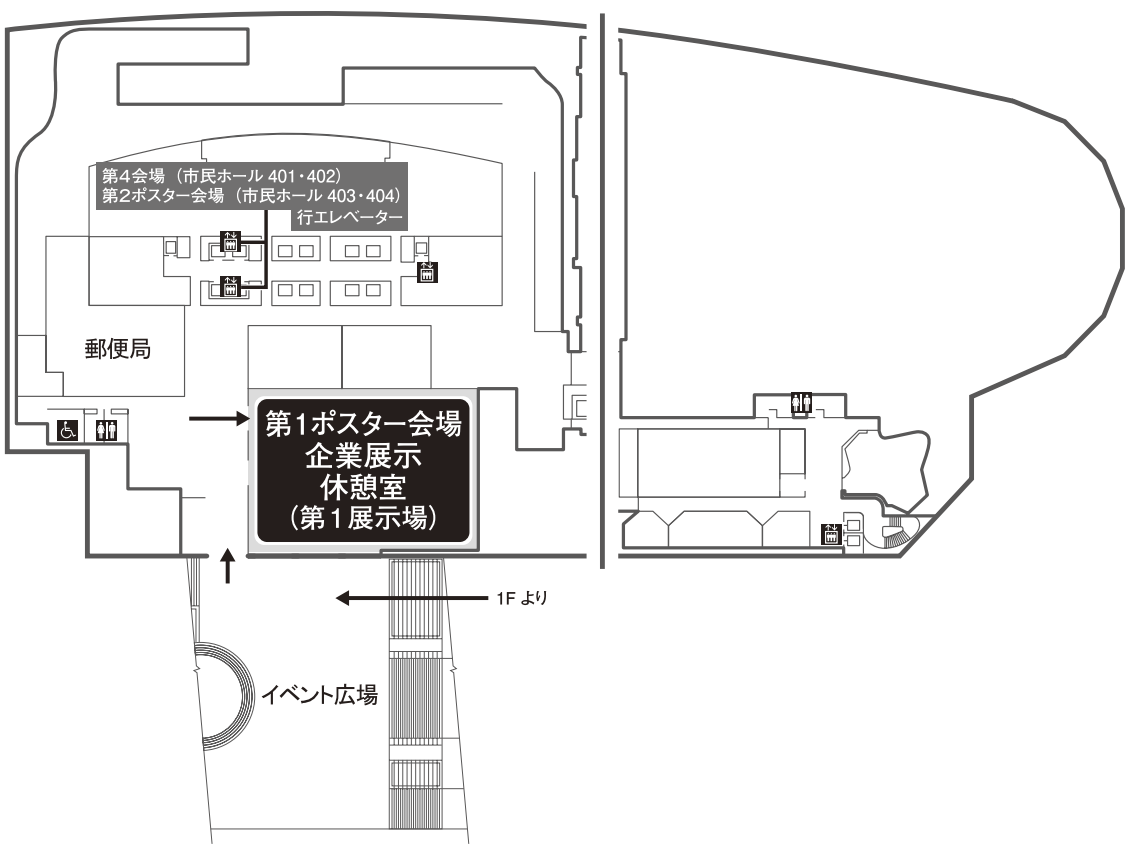




\section{$1 \mathrm{~F}$}

※各建物は,つながって おりません。

各建物間の移動は, 1F·2Fからとなります。

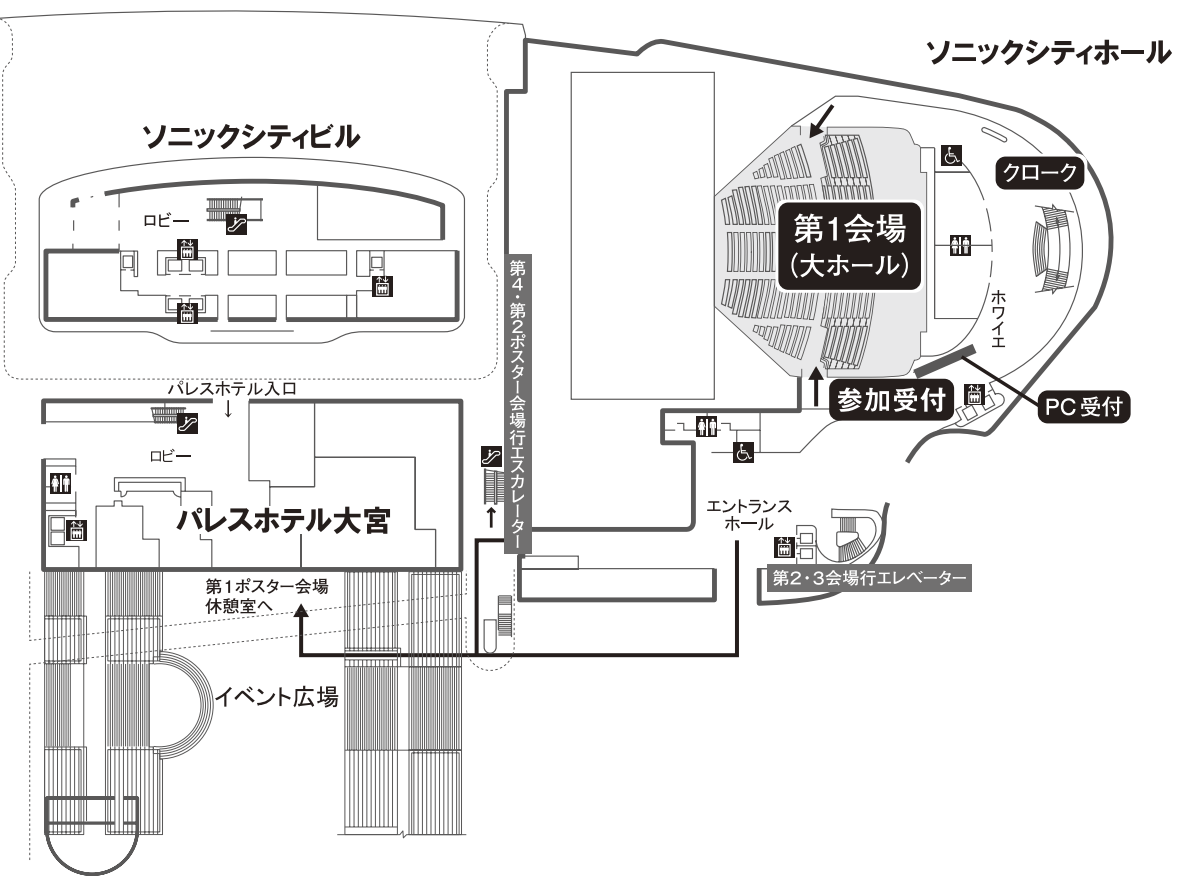

\section{$2 \mathrm{~F}$}
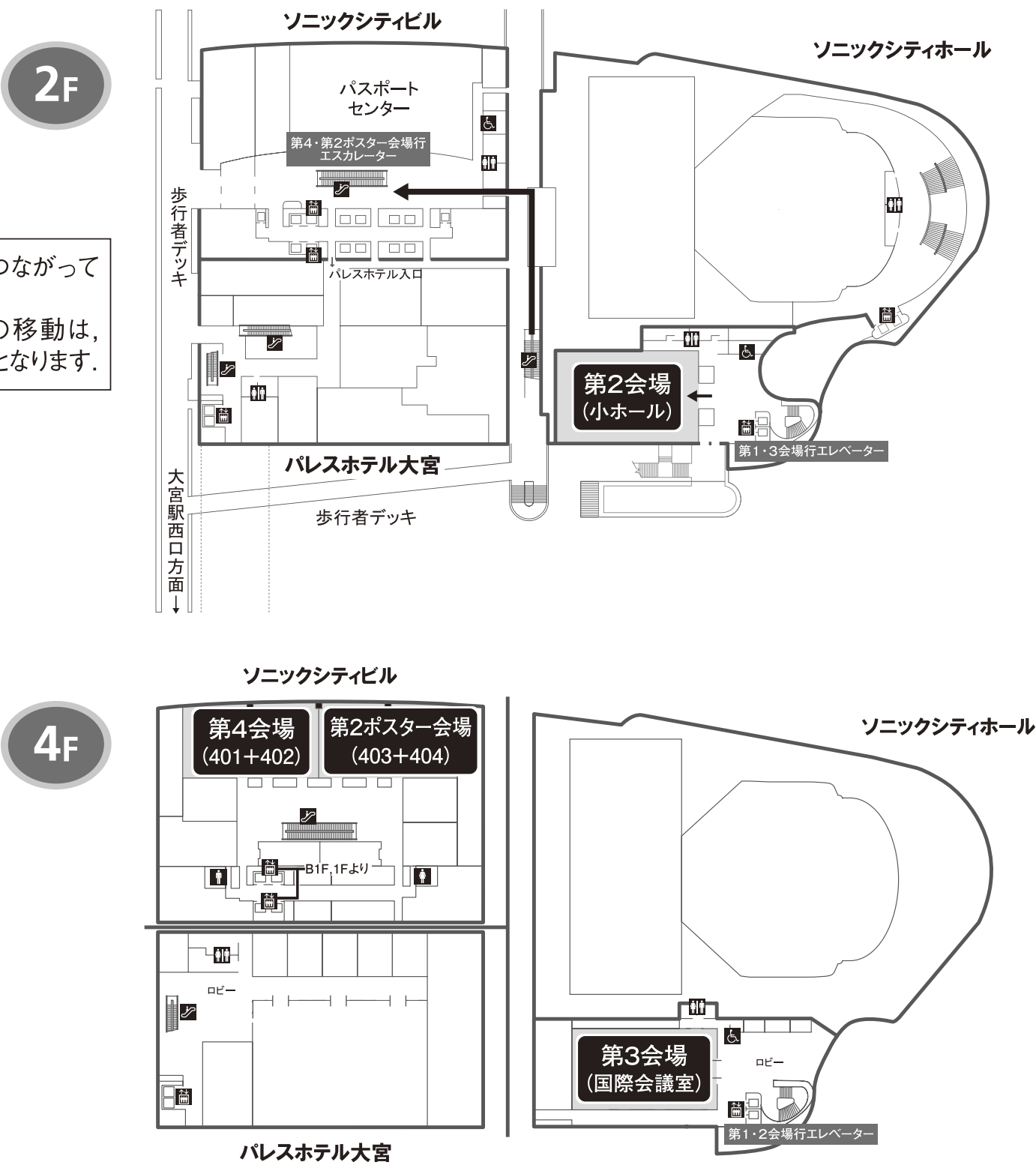


\section{臨床内分泌代謝 Update での専門医単位登録について}

内分泌代謝科専門医資格を取得されている方は、臨床内分泌代謝 Updateへのご出席で、更新研修単位として 10 単 位が付与されます。

学会期間中、日本内分泌学会事務局受付にて、単位登録票を発行致します。

専門医の方はご出席頂いた際にお立ち寄り頂き、登録票のご提出をお願い致します。受付は学会期間中のみとなって おり、学会終了後、また代理の方のご提出はお受けできませんので、ご留意下さい。

更新規程(2013 年 4 月改訂)については下記をご確認下さい。

\section{専門医認定更新規程および単位数取得について}

\section{(更新規程一内規より拔粋一)}

内分泌代謝科専門医の更新は、専門医取得 5 年後、下記の 3 点を満たしている場合、申請可能である。

1. 専門医と認定された後も引き続き会員であること。

2. 更新申請時、基幹学会の認定医または専門医であること。

3. 過去 5 年間に 60 単位以上の総単位数を取得し、そのうち 40 単位は必須対象の講演会(下段表参照：備考欄 A)へ の参加により取得したものであること。

\begin{tabular}{|c|c|c|c|c|c|c|}
\hline & \multirow{2}{*}{\multicolumn{2}{|c|}{ 単位取得：対象講習会 }} & \multicolumn{2}{|c|}{ 取得単位数 } & \multirow{2}{*}{ 備考 } \\
\hline & & & & 参加 & 演者 & \\
\hline \multirow{6}{*}{ 本 } & \multirow{6}{*}{ 会 } & \multicolumn{2}{|l|}{ 学術総会 } & 10 & 5 & \multirow{6}{*}{$\mathrm{A}$} \\
\hline & & \multicolumn{2}{|l|}{ 臨床内分泌代謝 Update } & 10 & 5 & \\
\hline & & \multicolumn{2}{|l|}{ 生涯教育講習会 } & 5 & 0 & \\
\hline & & \multicolumn{2}{|l|}{ 内分泌代謝学サマーセミナー } & 5 & 0 & \\
\hline & & \multicolumn{2}{|l|}{ 支部学術集会 ( 9 支部) 丸 } & 5 & 2 & \\
\hline & & \multicolumn{2}{|l|}{ 県単位の学術集会丸 } & 2 & 0 & \\
\hline \multirow{3}{*}{\multicolumn{2}{|c|}{ 科 }} & 日本甲状腺学会 & 日本神経内分泌学会 & \multirow{3}{*}{5} & \multirow{3}{*}{2} & \\
\hline & & 日本ステロイドホルモン学会 & 日本生殖内分泌学会 & & & \\
\hline & & 日本心血管内分泌代謝学会 & 日本内分泌病理学会 & & & \\
\hline \multicolumn{2}{|c|}{ 本会指定学会 } & \multicolumn{2}{|c|}{ 日本医学会総会 } & 7 & 0 & \\
\hline \multirow{6}{*}{ 基幹学会 } & \multirow{2}{*}{ 内 科 系 } & \multicolumn{2}{|c|}{ 日本内科学会(年次学術集会および地方会) } & \multirow{6}{*}{3} & \multirow{6}{*}{0} & \\
\hline & & 日本小児科学会(年次学術集会) & 日本産科婦人科学会(年次学術集会) & & & \\
\hline & \multirow{2}{*}{ 小児科系 } & \multicolumn{2}{|c|}{ 日本小児科学会(年次学術集会および地方会) } & & & \\
\hline & & 日本内科学会(年次学術集会) & 日本産科婦人科学会(年次学術集会) & & & \\
\hline & \multirow{2}{*}{ 産婦人科系 } & \multicolumn{2}{|c|}{ 日本産科婦人科学会(年次学術集会および地方会) } & & & \\
\hline & & 日本内科学会(年次学術集会) & 日本小児科学会(年次学術集会) & & & \\
\hline \multirow{7}{*}{\multicolumn{2}{|c|}{$\begin{array}{c}\text { 関 連 学 会 } \\
\text { (年次学術集会のみ) }\end{array}$}} & 日本小児内分泌学会 & & 5 & & \\
\hline & & 日本糖尿病学会 & 糖尿病学の進歩 & & & \\
\hline & & 日本臨床分子医学会 & 日本骨代謝学会 & & & 上 \\
\hline & & 日本肥満学会 & 日本アンドロロジー学会 & & 0 & 記 \\
\hline & & 日本痛風・核酸代謝学会 & 日本動脈硬化学会 & 2 & & 外 \\
\hline & & 日本内分泌外科学会 & ホルモンと癌研究会 & & & \\
\hline & & 日本間脳下垂体腫瘍学会 & $\begin{array}{l}\text { 日本小児内分泌学会 } \\
\text { 小児内分泌専門セミー }\end{array}$ & & & \\
\hline & & 国際内分泌学会 & & 5 & & \\
\hline & & 国際糖尿病連合学会 & 国際甲状腺学会 & & & \\
\hline & & 国際神経内分泌学会 & 国際カルシウム調節ホルモン学会 & & & \\
\hline そ & の＼cjkstart他 & アジア大洋州内分泌学会 & アジア大洋州甲状腺学会 & & & \\
\hline 特に指只 & 定した学会 & 国際ステロイドホルモン学会 & 国際アンドロロジー学会 & 0 & 0 & \\
\hline （年次学行 & 㭪集会のみ） & 世界小児内分泌学会 & 米国内分泌学会 & 2 & & \\
\hline & & 米国糖尿病学会 & 米国甲状腺学会 & & & \\
\hline & & 間脳・下垂体・副腎系研究会 & 痛風研修会 & & & \\
\hline & & 日本骨粗鬆症学会 & & & & \\
\hline
\end{tabular}

\section{注意事項}

表丸 支部および県単位の学術集会については取得単位として認められる回数：1年度につき各々 2 回まで 一支部合計 10 単位 /県合計 4 単位まで (参加回数の制限は設けない) 一 
プログラム 


\section{日 程 表}

1日目 11 月 28 日 (金)

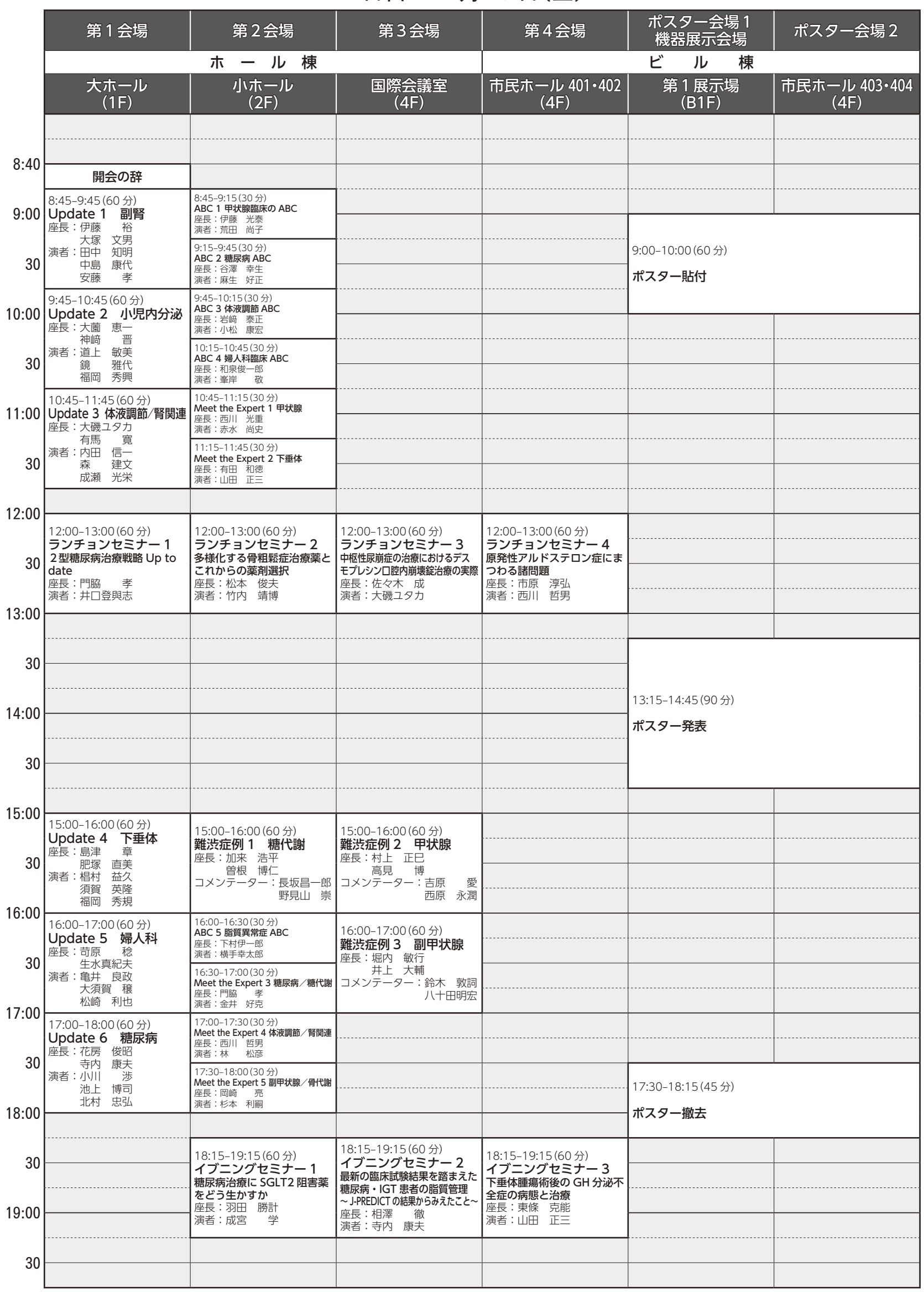


2日目 11 月 29 日 (土)

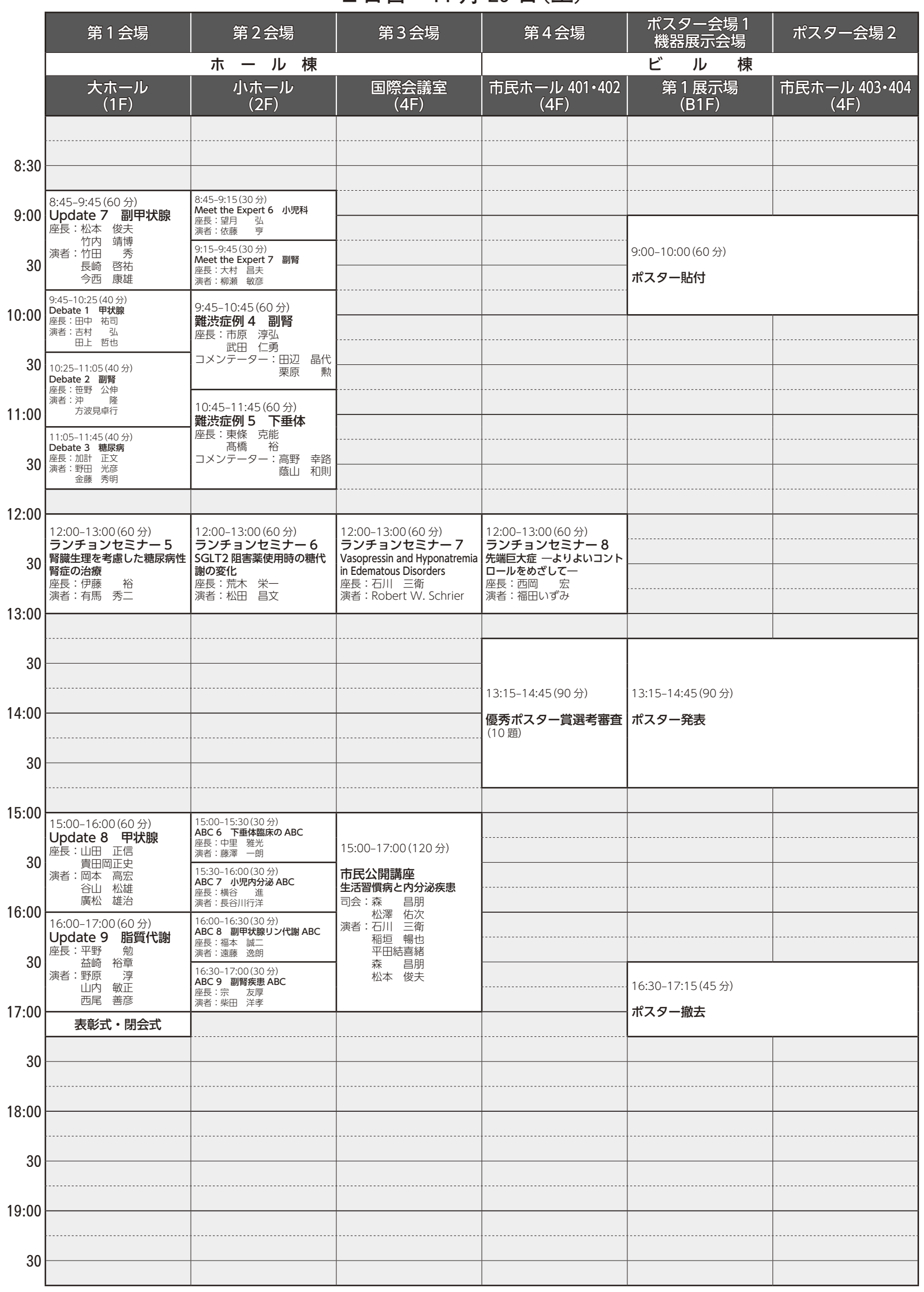




\section{プログラム概要}

\section{Update}

座長 慶應義塾大学 医学部 腎臟内分泌代謝内科

岡山大学大学院 医歯薬学総合研究科 総合内科学

伊藤裕

大塚 文男

1 AIMAH の病因と病態生理の最新の話題

演者 千葉大学大学院 医学研究院 細胞治療内科学

田中 知明

千葉大学医学部附属病院 糖尿病代謝内分泌内科

$2 \mathrm{KCNJ5}$ 変異と原発性アルドステロン症

演者 群馬大学大学院 医学系研究科病態制御内科学

中島 康代

3（プロ）レニン受容体と副腎腫瘍

演者 東京女子医科大学 高血圧・内分泌内科

安藤 孝

座長 大阪大学大学院 医学系研究科 小児科学

大薗 恵一

鳥取大学 医学部 周産期・小児医学分野

神㠃晋

1 ビタミンD 欠乏症 Update

演者 大阪府立母子保健総合医療センター研究所 環境影響部門

道上 敏美

2 インプリンティング異常と成長障害

演者 (独)国立成育医療研究センター研究所 分子内分泌研究部鏡 雅代

3 胎生期エピゲノム変化と小児内分泌の Update

演者 早稲田大学総合研究機構

福岡 秀興

座長 名古屋大学大学院 医学系研究科 糖尿病 - 内分泌内科学

大磯ユタカ

名古屋大学大学院 医学系研究科 糖尿病 - 内分泌内科学

有馬寛

1 希少疾患から学ぶ新たな血圧調節機構 一偽性低アルドステロン症 II 型と WNK キナーゼー 演者 東京医科歯科大学 腎臟内科

内田 信一

2 体液貯留における腎循環動態と内分泌調節

演者 東北大学大学院 医学系研究科 腎高血圧内分泌学分野

森建文

3 カリウム代謝と高血圧

演者 国立病院機構 京都医療センター 内分泌代謝高血圧研究部

成瀬 光栄

座長 独立行政法人国立病院機構 京都医療センター 臨床研究センター

東京女子医科大学 高血圧・内分泌内科

1 リンパ球性漏斗下垂体後葉炎のバイオマーカー 抗ラブフィリン $3 a$ 抗体

演者 名古屋大学大学院 医学系研究科 糖尿病 - 内分泌内科学
島津章

肥塚 直美

椙村 益久 他 
2 多能性幹細胞を用いた視床下部・下垂体研究

演者 名古屋大学医学部附属病院 糖尿病 - 内分泌内科、 理化学研究所 再生・発生科学総合研究センター

須賀 英隆 他

3 クッシング病の薬物療法 〜現況と今後の展望〜

演者 神戸大学医学部附属病院 糖尿病 - 内分泌内科

福岡 秀規 他

11月 28 日(金) $16: 00 \sim 17: 00$

座長 徳島大学大学院 ヘルスバイオサイエンス研究部 産科婦人科学

苛原稔

千葉大学大学院 医学研究院 生殖医学

生水真紀夫

1 妊娠中の糖代謝異常の管理 Up To Date

演者 埼玉医科大学病院 産婦人科

亀井 良政

2 子宮内膜症の Update 一病態についての新たな展開一

演者 東京大学大学院 医学系研究科 産婦人科学講座 大須賀 穣

3 PCOS の排卵誘発におけるメトホルミン

演者 徳島大学大学院 ヘルスバイオサイエンス研究部 産科婦人科学分野松崎 利也

座長 大阪医科大学 内科学 I

花房 俊昭

横浜市立大学大学院 医学研究科 分子内分泌 - 糖尿病内科学

寺内 康夫

1 脂肪組織のインスリン作用と代謝制御

演者 神戸大学大学院 医学研究科 糖尿病 - 内分泌内科学

小川 渉

21 型糖尿病の成因：なぜ膵 $\beta$ 細胞だけが破壊されるのか?

演者 近畿大学 医学部 内分泌・代謝・糖尿病内科

池上 博司

3 糖尿病におけるグルカゴン動態

演者 群馬大学生体調節研究所・代謝シグナル解析分野

北村 忠弘

座長 徳島大学 藤井節郎記念医科学センター

松本 俊夫

虎の門病院 内分泌センター

竹内 靖博

1 骨代謝制御機構に関する最近の進歩

演者 東京医科歯科大学大学院 医歯学総合研究科 細胞生理学分野竹田秀

2 偽性副甲状腺機能低下症の病因と病態

演者 新潟大学大学院 医歯学総合研究科 小児科長崎 啓祐

3 原発性副甲状腺機能元進症の内科的治療

演者 大阪市立大学大学院 医学研究科 代謝内分泌病態内科学

今西 康雄

座長 群馬大学大学院 医学系研究科 病態制御内科学

山田 正信

公立昭和病院 内分泌・代謝内科

貴田岡正史

1 甲状腺腫瘍診療ガイドライン

演者 東京女子医科大学 内分泌外科, 衛生学公衆衛生学 II

岡本 高宏 
2 不適切 TSH 分泌症候群 (SITSH)

演者 昭和大学 医学部 内科学講座 糖尿病・代謝・内分泌内科学部門 藤が丘病院 内分泌代謝科

谷山 松雄

3 甲状腺眼症 update

演者 久留米大学 医学部 内科学講座 内分泌代謝内科部門廣松 雄治

11月 29 日(土) $16: 00 \sim 17: 00$

座長 昭和大学 医学部 内科学講座 糖尿病・代謝・内分泌内科部門

平野勉

琉球大学大学院 医学研究科 内分泌代謝 - 血液・膠原病内科学講座 (第二内科) 益崎 裕章

1 脂質代謝異常症の新たな標的 PCSK9

演者 金沢大学大学院 医薬保健学総合研究科 脂質研究講座野原淳

2 脂質異常とアディポネクチン

演者 東京大学大学院 医学系研究科 糖尿病・代謝内科

山内 敏正 他

3 脂質代謝と動脈硬化 〜リポ蛋白代謝に基づく考察〜

演者 鹿児島大学大学院 医歯学総合研究科 糖尿病内分泌内科学 西尾 善彦

\section{Meet the Expert}

甲状腺クリーゼの診療と予後改善

座長 関西医科大学 第 2 内科

西川 光重

演者 和歌山県立医科大学 内科学第一講座

赤水 尚史

下垂体腫瘍に対する集学的治療

座長 鹿児島大学大学院 医歯学総合研究科 脳神経外科学

有田 和徳

演者 虎の門病院 間脳下垂体外科

山田 正三

Meet the Expert 3 糖尿病 / 糖代謝

第 2会場 小ホール)

11 月 28 日(金) $16: 30 \sim 17: 00$

SGLT2 の発見亡その後の臨床展開

座長 東京大学大学院 医学系研究科 内科学専攻 生体防御腫瘍内科学講座 代謝・栄養病態学

門脇＼cjkstart孝

演者 大阪大学大学院 医学系研究科 生体システム薬理学

金井 好克

Gitelman 症候群、Bartter 症候群および類縁疾患

座長 横浜労災病院 内科西川 哲男

演者 慶應義塾大学 医学部 血液浄化・透析センター 総合診療教育センター 林 松彦 
骨粗鬆症治療の最前線

座長 帝京大学ちば総合医療センター 第三内科

岡崎亮

演者 島根大学 医学部 内科学講座内科学第一

杉本 利嗣

Meet the Expert 6 小览科

第 2 会場 (小ホール)

11 月 29 日(土) $8: 45 \sim 9: 15$

小児の低血糖症 : Update

座長 埼玉県立小児医療センター 代謝内分泌科

望月弘

演者 大阪市立総合医療センター 小児代謝・内分泌内科

依藤 亨

11月 29 日(土) $9: 15 \sim 9: 45$

副腎癌の病態と治療

座長 横浜労災病院 内分泌・糖尿病センター

大村 昌夫

演者 福岡大学 医学部 内分泌・糖尿病内科

柳瀬 敏彦

\section{$\mathrm{ABC}$}

$A B C 1$ 甲状腺：甲状腺臨床の $A B C$

第 2 会場 (小ホール)

11月 28 日(金) $8: 45 \sim 9: 15$

妊娠と甲状腺

座長 藤田保健衛生大学 医学部 内分泌・代謝内科学 伊藤 光泰

演者 独立行政法人国立成育医療研究センター 周産期・母性診療セン夕ー 母性内科 荒田 尚子

$A B C 2$ 糖尿病 $/$ 糖代謝 : 糖尿病 $A B C$

第 2会場(小ホール)

11月28日(金) $9: 15 \sim 9: 45$

2 型糖尿病治療の新たな方向性

座長 山口大学大学院 医学系研究科 病態制御内科学

谷澤 幸生

演者 獨協医科大学 内科学(内分泌代謝)

麻生 好正

$A B C 3$ 体液調節 $/$ 腎関連 : 体液調節 $A B C$

第 2 会場(小ホール)

11月 28 日(金) $9: 45 \sim 10: 15$

低ナトリウム血症の臨床的課題一数值目標から臨床的アウトカム改善へ

座長 高知大学 臨床医学部門

岩㠃 泰正

演者 聖路加国際病院 腎臟内科

小松 康宏

$A B C 4$ 婦人科／性ホルモン：婦人科臨床 $A B C$

第2会場(小ホール)

11 月 28 日(金) $10: 15 \sim 10: 45$

卵巣機能調節

座長 東海大学 医学部 専門診療学系産婦人科学

和泉俊一郎

演者 群馬大学大学院 医学系研究科 産科婦人科学

峯岸敬 
脂質異常症：診断と治療の $A B C$

座長 大阪大学大学院 医学系研究科 内分泌 - 代謝内科学

下村伊一郎

演者 千葉大学大学院 医学研究院 細胞治療内科学講座

横手幸太郎

ABC 6 下垂体：下垂体臨床の ABC 第 2 会場 (小ホール)

11 月 29 日(土) $15: 00 \sim 15: 30$

下垂体疾患の MRI の読み方

座長 宮崎大学 医学部 内科学講座 神経呼吸内分泌代謝学分野

中里 雅光

演者 市立岸和田市民病院 放射線科

藤澤 一朗

$A B C 7$ 小児科：小児内分泌 $A B C$

第 2会場(小ホール)

11 月 29 日(土) $15: 30 \sim 16: 00$

性早熟異常症の臨床

座長 国立成育医療研究セン夕一 生体防御系内科部

横谷進

演者 東京都立小児総合医療センター 内分泌・代謝科

長谷川行洋

$A B C 8$ 副甲状腺 / $C a$ ：副甲状腺リン代謝 $A B C$

第 2 会場 (小ホール)

11 月 29 日(土) $16: 00 \sim 16: 30$

低リン血症への実践的アプローチ

座長 東京大学医学部附属病院 腎臟・内分泌内科

福本 誠二

演者 徳島大学病院 内分泌代謝内科

遠藤 逸朗

$A B C 9$ 副腎：副腎疾患 $A B C$

第 2 会場 小ホール)

11 月 29 日(土) $16: 30 \sim 17: 00$

副腎不全の治療の現状と展望

座長 川崎医科大学 糖尿病 - 代謝 - 内分泌内科学

宗友厚

演者 大分大学 医学部 内分泌代謝・膠原病・腎臟内科学講座

柴田 洋孝 


\section{ディベートセッション}

バセドウ病治療を完了するには

座長 防衛医科大学校 総合臨床部 /内分泌 - 代謝内科

田中 祐司

演者 伊藤病院

吉村弘

国立病院機構 京都医療センター 内分泌・代謝内科

田上 哲也

Subclinical Cushing 症候群は overt の前段階?

座長 東北大学大学院 医学系研究科医科学専攻 病理病態学講座 病理診断学分野 笹野 公伸

演者 浜松医科大学 地域家庭医療学内分泌代謝内科

沖隆

聖マリアンナ医科大学横浜市西部病院 代謝・内分泌内科

方波見卓行

糖尿病の経口薬の使い方 (第 2 選択薬について 従来薬か新薬か ?)

座長 自治医科大学附属さいたま医療センター 総合医学 1

加計 正文

演者 国立国際医療研究センター 糖尿病研究部

野田 光彦

川崎医科大学 糖尿病 - 代謝 - 内分泌内科学教室

金藤 秀明 


\begin{tabular}{|c|c|c|c|c|c|}
\hline & 類 & 発表時間 & 座 & 長 & 所 \\
\hline & 下垂体 1 ／クッシング病 1 & $13: 15-14: 00$ & 松野 & 彰 & 帝京大学医学部 脳神経外科 \\
\hline & 下垂体 2 ／クッシング病 2 & $14: 00-14: 45$ & 鈴木(堀 & 田）県理 & 政策研究大学院大学 保健管理センター \\
\hline & 下垂体 3 ／先端巨大症 1 & $13: 15-14: 00$ & 田原 & 重志 & 日本医科大学 脳神経外科 \\
\hline & 下垂体 4／下垂体腫瘍 1 & $14: 00-14: 45$ & 西岡 & 宏 & 虎の門病院 内分泌センター 間脳下垂体外科 \\
\hline & 下垂体 5 ／下垂体機能低下症 1 & $13: 15-14: 00$ & 大月 & 道夫 & 大阪大学大学院医学系研究科 内分泌 - 代謝内科 \\
\hline & 下垂体 6 ／下垂体炎 1 & $14: 00-14: 45$ & 清水 & 力 & 北海道大学病院 検査・輸血部 \\
\hline & 下垂体 7 ／ADH 分泌異常症・電解質異常 & $13: 15-14: 00$ & 高木 & 潤子 & 愛知医科大学医学部 内科学講座 内分泌・代謝内科 \\
\hline & 甲状腺 1 ／バセドゥ病 1 & $14: 00-14: 45$ & 江本 & 直也 & 日本医科大学千葉北総病院 内分泌内科 \\
\hline & 甲状腺 2 ／バセドウ病 2 & $13: 15-14: 00$ & 宮川 & めぐみ & 虎の門病院 内分泌代謝科 \\
\hline & 甲状腺 3 ／甲状腺腫瘍・その他 & $14: 00-14: 45$ & 杉谷 & 嚴 & 日本医科大学 内分泌外科学 \\
\hline 多 & 副腎 1／クッシング症候群 1 & $13: 15-14: 00$ & 上芝 & 元 & 東邦大学医学部 内科学 糖尿病・代謝・内分泌学分野 \\
\hline & 副腎 2 ／クッシング症候群 2 & $14: 00-14: 45$ & 齊藤 & 智之 & 自治医科大学附属さいたま医療センター 内分泌代謝科 \\
\hline 場 & 副腎 $3 ／$ 副腎腫瘍 & $13: 15-14: 00$ & 菊森 & 豊根 & 名古屋大学医学部附属病院 乳腺・内分泌外科 \\
\hline & 副腎 4／原発性アルドステロン症 1 & $14: 00-14: 45$ & 佐藤 & 文俊 & 東北大学病院 腎・高血圧・内分泌科 \\
\hline & 副腎 5／褐色細胞腫 1 & $13: 15-14: 00$ & 竹越 & 一博 & 筑波大学医学医療系臨床医学域 \\
\hline & 副腎 6 ／褐色細胞腫 2 & $14: 00-14: 45$ & 臼井 & 健 & 国立病院機構京都医療センター 臨床研究センター \\
\hline & 糖代謝 $1 / 1$ 型糖尿病・DKA & $13: 15-14: 00$ & 山田 & 祐一郎 & 秋田大学大学院医学系研究科 内分泌・代謝 $\cdot$ 老年内科学 \\
\hline & 糖代謝 $2 / 2$ 型糖尿病・ステロイド糖尿病 & $14: 00-14: 45$ & 小川 & 佳宏 & 東京医科歯科大学 糖尿病・内分泌・代謝内科 \\
\hline & 性腺 1 & $13: 15-14: 00$ & 緒方 & 勤 & 浜松医科大学 小児科学講座 \\
\hline & 糖代謝 3 ／インスリノーマ 1 & $14: 00-14: 45$ & 植木 & 浩二郎 & 東京大学医学部 糖尿病・代謝内科 分子糖尿病科学講座 \\
\hline & 小児内分泌 & $13: 15-14: 00$ & 堀川 & 玲子 & 国立成育医療研究センター 内分泌代謝科 \\
\hline & 肥満・掑食障害 & $14: 00-14: 45$ & 野牛 & 宏晃 & 筑波大学附属病院水戸地域医療教育センター 内分泌代謝·糖尿病内科 \\
\hline & 骨カルシウム代謝 1 ／原発性副甲状腺機能方進症 1 & $13: 15-14: 00$ & 田口 & 学 & 東京大学医学部附属病院 腎臟内分泌内科 \\
\hline & 骨力ルシウム代㴬 2 /原発性副甲状腺機能元進症 2 ・高力ルシウム血症 & $14: 00-14: 45$ & 難波 & 範行 & 大阪大学大学院医学系研究科 小児科学 \\
\hline 多 & 研修医・学生部門＼cjkstart糖尿病・低血糖 & $13: 15-14: 00$ & 石橋 & 俊 & 自治医科大学 内科学講座 内分泌代謝科 \\
\hline & 研修医·学生部門 下垂体 1 / 先端巨大症・TSH 産生下垂体腫場 & $14: 00-14: 45$ & 三木 & 伸泰 & 新百合ヶ丘総合病院 内分泌代謝内科 \\
\hline 場 & 研修医・学生部門 甲状腺 & $13: 15-14: 00$ & 佐藤 & 哲郎 & 群馬大学医学部附属病院 内分泌糖尿病内科 \\
\hline & 研修医・学生部門 下垂体 $2 /$ /クシング病・その他 & $14: 00-14: 45$ & 金本 & 巨哲 & 大阪市立総合医療センター 内分泌内科 \\
\hline
\end{tabular}

\begin{tabular}{|c|c|c|c|c|}
\hline & 分 類 & 発表時間 & 座 & 所 属 \\
\hline & 下垂体 8／クッシング病 3 & $13: 15-14: 00$ & 在原 善英 & 仙台医療センター 内分泌代謝内科 \\
\hline & 下垂体 9 /先端巨大症 2 & $14: 00-14: 45$ & 杉原 & 日本医科大学大学院医学研究科 内分泌糖尿病代謝内科学 \\
\hline & 下垂体 10 /下垂体腫瘍 2 - その他 & $13: 15-14: 00$ & 小野 & 新百合ヶ丘総合病院 内分泌代謝 \\
\hline & 下垂体 11 ／下垂体機能低下症 2 & $14: 00-14: 45$ & 西山 & 高知大学医学部 内分泌代謝・腎臟内科 \\
\hline & 下垂体 $12 ／$ 下垂体機能低下症 3 & $13: 15-14: 00$ & 菅原 & 東北大学大学院医学系研究科 分子内分泌学分野 \\
\hline & 下垂体 13 ／下垂体炎 2 & $14: 00-14: 45$ & いずみ & 東京女子医科大学 高血圧・内分泌内科 \\
\hline & 甲状腺 4 ／その他の甲状腺機能元進症 & $13: 15-14: 00$ & 久保田＼cjkstart憲 & がん感染症センター都立駒込病院 糖尿病・内分泌内科 \\
\hline & 甲状腺 5 ／甲状腺機能低下症 & $14: 00-14: 45$ & 大塚 史子 & 昭和大学藤が丘病院 内分泌代謝科 \\
\hline 棸 & 副腎 7 ／クッシング症候群 3 & $13: 15-14: 00$ & 育代 & 自治医科大学附属さいたま医療センター 内分泌代謝科 \\
\hline 多 & 副腎 8／Gitelman 症候群・副腎出血 & $14: 00-14: 45$ & 洋通 & 埼玉医科大学 腎臓内科 \\
\hline & 副腎 9／副腎皮質機能低下症・その他 & $13: 15-14: 00$ & 七里 & 北里大学医学部 内分泌代謝内科学 \\
\hline 場 & 副腎 10 ／原発性アルドステロン症 2 & $14: 00-14: 45$ & 寺田 & 高知大学医学部 内分泌代謝 - 腎臓内科学教室 \\
\hline & 副腎 11 /原発性アルドステロン症 3 & $13: 15-14: 00$ & 齋藤 & 横浜労災病院 内分泌糖尿病センター \\
\hline & 副腎 $12 ／$ 褐色細胞腫 3 & $14: 00-14: 45$ & 橋本 & 福島県立医科大学 放射線医学県民健康管理センター \\
\hline & 糖代謝 4 ／糖尿病治療 & $13: 15-14: 00$ & 犬飼 & 学越谷病院 糖尿病内分泌・血液内科 \\
\hline & 糖代謝 5 /脂質・その他 & $14: 00-14: 45$ & 大門 & 弘前大学大学院医学研究科 内分泌代謝内科 \\
\hline & 糖代謝 6 ／低血糖 1 & $13: 15-14: 00$ & 吉岡 & 札幌病院 糖尿病内分泌内科 \\
\hline & 糖代謝 7 ／インスリノーマ 2 ・低血糖 2 & $14: 00-14: 45$ & 佐倉 & 東京女子医科大学 東医療センター 内科 \\
\hline & 性腺 2 & $13: 15-14: 00$ & 堂地 & 鹿児島大学大学院医歯学総合研究科 生殖病態生理学 \\
\hline & 多発性内分泌腫瘍症 & $14: 00-14: 45$ & 今井 & 愛知医科大学 乳腺・内分泌外科 \\
\hline & 骨カルシウム代謝 $3 / \mathrm{PTHrP}$ 産生腫瘍·副甲状腺癌 & $13: 15-14: 00$ & 山本 & 島根大学医学部 内科学講座 内科学第一 \\
\hline 多 & 骨カルシウム代謝 4 ／その他 & $14: 00-14: 45$ & 山口 & 島根大学医学部 内科学第一 \\
\hline & 研修医·学生部門 下垂体 $3 /$ 尿崩症・下垂体機能低下症・下垂体炎 & $13: 15-14: 00$ & 村瀬 孝司 & 国立病院機構名古屋医療センター 糖尿病・内分泌内科 \\
\hline 会 & 研修医・学生部門 副腎 $1 ・ そ の$ 他 & $14: 00-14: 45$ & 海老原 健 & 自治医科大学医学部 内科学講座 内分泌代謝学部門 \\
\hline 2 & 研修医·学生部門 副腎 2 /褐色細胞腪・クッシング症候群 & $13: 15-14: 00$ & 飯野 和美 & JA 静岡厚生連 遠州病院 内分泌内科 \\
\hline
\end{tabular}




\section{1 月 28 日(金)}

2 型糖尿病治療戦略 Up to date

座長 東京大学大学院 医学系研究科 糖尿病 - 代謝内科

門脇 孝

演者 九州大学 先端融合医療レドックスナビ研究拠点

井口登與志

共催 MSD 株式会社

ランチョンセミナー 2

第 2 会場 (小ホール)

多様化する骨粗鬆症治療薬とこれからの薬剤選択

座長＼cjkstart徳島大学＼cjkstart藤井節郎記念医科学センター

松本 俊夫

演者 国家公務員共済組合連合会 虎の門病院 内分泌センター

竹内 靖博

共催 第一三共株式会社

ランチョンセミナー 3

第3会場(国際会議室)

中枢性尿崩症の治療におけるデスモプレシンロ腔内崩壊錠治療の実際

座長 医療法人社団 清湘会 顧問/東京医科歯科大学 名誉教授

佐々木 成

演者 名古屋大学大学院 医学系研究科 糖尿病 - 内分泌内科学

大磯ユタカ

共催 フェリング・ファーマ株式会社/協和発醳キリン株式会社

ランチョンセミナー 4

第4会場(市民ホール401・402)

原発性アルドステロン症にまつわる諸問題

座長 東京女子医科大学 高血压・内分泌内科

市原 淳弘

演者 横浜労災病院

西川 哲男

共催 大日本住友製薬株式会社

糖尿病治療に SGLT2 阻害薬をどう生かすか

座長 旭川医科大学病院 内科学講座 病態代謝内科学分野

羽田 勝計

演者 西埼玉病院

成宮学

共催 アストラゼネカ株式会社

イブニンブセミナー 2

最新の臨床試験結果を踏まえた糖尿病・IGT 患者の脂質管理

〜 J-PREDICT の結果からみえたこと〜

座長 相澤病院＼cjkstart糖尿病センター 顧問

相澤 徹

演者 横浜市立大学大学院 医学研究科 分子内分泌・糖尿病内科学教室

寺内 康夫

共催 興和創薬株式会社 
イブニングセミナー 3

第4会場(市民ホール401・402)

下垂体腫瘍術後の $\mathrm{GH}$ 分泌不全症の病態と治療

座長 東京慈恵会医科大学附属柏病院 糖尿病 - 代謝 - 内分泌内科

東條 克能

演者 国家公務員共济組合連合会 虎の門病院 間脳下垂体外科

山田 正三

共催 日本イーライリリー株式会社

\section{1 月 29 日(土)}

腎臟生理を考慮した糖尿病性腎症の治療

座長 慶應義塾大学 医学部 腎臟内分泌代謝内科

伊藤 裕

演者 近畿大学 医学部 腎臟内科

有馬 秀二

共催 武田薬品工業株式会社

ランチョンセミナー6

第 2 会場(小ホール)

SGLT2 阻害薬使用時の糖代謝の変化

座長 熊本大学大学院 生命科学研究部 代謝内科学

荒木 栄一

演者 埼玉医科大学総合医療センター 内分泌・糖尿病内科

松田 昌文

共催 田辺三菱製薬株式会社

ランチョンセミナー7

Vasopressin and Hyponatremia in Edematous Disorders

座長 自治医科大学附属さいたま医療センター 内分泌代謝科

石川 三衛

演者 Professor Emeritus of Medicine University of Colorado Denver Division of

Renal Diseases \& Hypertension

Robert W. Schrier

共催 大塚製薬株式会社

ランチョンセミナー 8

第4会場(市民ホール401・402)

先端巨大症 一よりよいコントロールをめざしてー

座長 虎の門病院 間脳下垂体外科

西岡宏

演者 東京女子医科大学 高血圧・内分泌内科

福田いずみ

共催 ノバルティスファーマ株式会社 


\section{市民公開講座 11月29日(土） 15:00～17:00 第3会場 (国際会議室)}

\section{メインテーマ：『生活習慣病と内分泌疾患』 \\ 司会：森 昌朋 北関東肥満代謝研究所 所長 \\ 松澤 佑次 一般財団法人住友病院 院長}

\section{開会挨拶}

認定 NPO 法人 日本ホルモンステーション＼cjkstart理事長

京都大学大学院 医学研究科 メディカルイノベーションセンター 教授

中尾一和

\section{はじめに}

第 24 回臨床内分泌 Update 会長

自治医科大学附属さいたま医療センター 教授

石川 三衛

講演1＼cjkstart糖尿病治療：最新の進歩

京都大学大学院 医学研究科 糖尿病 - 内分泌 - 栄養内科学 教授

稲坦 暢也

講演 2 内分泌性高血圧一治る高血圧

(公財) 先端医療振興財団先端医療センター病院 病院長

平田結喜緒

講演 3 甲状腺腫大に気付いたら

北関東肥満代謝研究所所長森昌朋

講演4＼cjkstart骨粗鬆症を予防するには

徳島大学藤井節郎記念医科学センター センター長松本 俊夫

※参加費無料。

※定員 200 名。事前申込不要。

共催：認定 NPO 法人日本ホルモンステーション

一般社団法人日本内分泌学会

第 24 回臨床内分泌代謝 Update

後援 : 埼玉県、さいたま市、埼玉県医師会、大宮医師会、埼玉新聞社 


\section{診断・治療に難渋した症例 (各症例の詳細は抄録をご覧ください)}

セッション 1 糖尿病(11月28日 金曜日 15:00～16:00)

第2会場(小ホール)

座長：加来 浩平(川崎医科大学 総合内科学 1)

曽根 博仁 (新潟大学大学院医歯学総合研究科 血液 - 内分泌 - 代謝内科)

コメンテーター：長坂昌一郎(自治医科大学 内科学講座 内分泌代謝学部門)

野見山 崇(福岡大学医学部 内分泌・糖尿病内科学)

C-1＼cjkstart神経障害と腎症を認める 2 型糖尿病患者とされた POEMS 症候群の一例

近江八幡市立総合医療センター 代謝 - 内分泌内科 村田幸一郎 他

C-2 インスリノーマによる難治性低血糖に対するエベロリムスの効果

東邦大学医療センター佐倉病院 糖尿病 - 内分泌 - 代謝センター 渡辺 怜奈 他

C-3 診断に難渋した malignant lactic acidosis の 1 例

高知大学 医学部 内分泌代謝 ・ 腎臟内科 谷口 義典 他

セッション 2 甲状腺(11月28日 金曜日 15:00～16:00)

第 3会場(国際会議室)

座長：村上 正巳(群馬大学大学院医学系研究科 臨床検査医学)

高見 博(伊藤病院/帝京大学医学部 名誉・客員教授)

コメンテーター：吉原愛(伊藤病院 内科)

西原 永潤(隈病院 内科)

C-4 TSH 異常高値を認めたマクロ TSH 血症の一例

大阪市立総合医療センター 総合診療科/内分泌内科 山上 啓子 他

C-5 TSHR 体細胞変異を伴う Plummer 病と PHPT の合併例

国立病院機構 京都医療センタ一内分泌・代謝内科／洛和会音羽病院 糖尿病内分泌内科 松尾奈緒美 他

C-6 甲状腺乳頭癌を合併した多発性内分泌腫瘍症 (MEN) 1 型の一例

岡山大学病院 腎臟・糖尿病・内分泌内科 /内分泌センター 越智可奈子 他

セッション3 副甲状腺(11月28日＼cjkstart金曜日１6:00～17:00)

第 3会場(国際会議室)

座長：堀内 敏行(東京都心身障害者福祉センター)

井上 大輔(帝京大学ちば総合医療センター 第三内科)

コメンテーター：鈴木 敦詞 (藤田保健衛生大学医学部 内分泌・代謝内科)

八十田明宏 (京都大学大学院医学研究科 糖尿病・内分泌・栄養内科)

C-7 デノスマブが奏効した転移性副甲状腺癌による高 Ca 血症の一例

勤医協中央病院 糖尿病 - 内分泌、腎臟病センター 系島 早織 他

C-8 Osteopathia Striata with Cranial Sclerosis の男性軽症例

京都大学 医学研究科 糖尿病 - 内分泌 - 栄養内科/洛和会音羽病院 内分泌内科 三浦 晶子 他

C-9 HRPT2 に新規変異を認めた家族性副甲状腺機能立進症の 1 例

昭和大学藤が丘病院 内分泌代謝科 杉澤 千穂 他 
座長：市原 淳弘(東京女子医科大学 高血圧・内分泌内科)

武田 仁勇 (金沢大学医薬保健研究域医学系 臓器機能制御学 (内科学第二))

コメンテーター：田辺 晶代(東京女子医科大学 第二内科)

栗原勲(慶應義塾大学医学部 腎臓・内分泌・代謝内科)

C-10＼cjkstart腰静脈へ合流する導出静脈でアルドステロン高值だった APA の 1 例

市立札幌病院 糖尿病 - 内分泌内科 芦原 順也 他

C-11 急激な発熱と急性呼吸促迫症候群を呈した褐色細胞腫の一例 虎の門病院内分泌センター 三ツ木 崇 他

C-12 高血圧症合併妊娠として経過をみられていた Cushing 症候群の 1 例

東邦大学医療センター大森病院 糖尿病・代謝・内分泌センター 八木 智子 他

セッション5 下垂体(11月29日土曜日１0:45～11:45)

第2会場(小ホール)

座長：東條 克能(東京慈恵会医科大学附属柏病院)

高橋裕(神戸大学大学院医学研究科 糖尿病・内分泌内科学)

コメンテーター：高野 幸路(北里大学病院 内分泌代謝内科)

蔭山＼cjkstart和則(弘前大学大学院医学研究科 内分泌代謝内科学講座)

C-13 3 回の陽子線治療を要した ACTH 産生下垂体癌総合南東北病院下垂体疾患研究所 池田 秀敏 他

C-14＼cjkstart高熱之慢性貧血を契機に発見された IL-6 産生下垂体腺腫の 1 例

獨協医科大学 医学部 内科学(内分泌代謝) 相良 匡昭 他

C-15下垂体膿瘍により汎下垂体機能低下症を呈した HIV 感染症の一例

京都大学医学部付属病院 糖尿病 - 内分泌 - 栄養内科 金井 有吾 他 


\section{優秀ポスター賞選考セッション 11 月 29 日(土)}

\section{$13: 15 \sim 14: 00$}

第4会場(市民ホール401＋402)

座長：稲垣 暢也(京都大学大学院医学研究科 糖尿病 - 内分泌 - 栄養内科学)

伊藤 光泰(藤田保健衛生大学医学部 内分泌・代謝内科学)

EP-1 Cushing 病の一带型 Crooke's cell adenoma の薬物感受性評価

虎の門病院 内分泌代謝科 林 恭秉 他

EP-2 SCS120 例の臨床的特徵と腫瘍の PRKACA 変異／遺伝子発現解析の検討

千葉大学大学院医学研究院 細胞治療内科学

千葉大学医学部附属病院 糖尿病代謝内分泌内科 樋口誠一郎 他

EP-3＼cjkstart新規エストロゲン受容体変異体の同定之機能解析

日本医科大学 大学院医学研究科 解剖学 - 神経生物学分野/脳神経外科学分野 服部裕次郎 他

EP-4 APA86 例における変異解析と RNA-seq から捉えた新たな分子病態

千葉大学大学院医学研究院 細胞治療内科学 河野 貴史 他

EP-5巨大卵巣囊腫を伴う機能性 FSH 産生下垂体腺腫 虎の門病院 間脳下垂体外科 福原 紀章 他

\section{$14: 00 \sim 14: 45$}

座長：羽田 勝計(旭川医科大学 内科学講座 病態代謝内科学分野)

横谷 進 （国立成育医療研究センター病院）

EP-6＼cjkstart先端巨大症においては末梢血テロメア長が短縮している

神戸大学大学院医学研究科糖尿病 - 内分泌内科学 松本 隆作 他

EP-7 抗 LCAT 抗体により低脂血症とネフローゼ症候群をきたした 1 例

千葉大学 大学院医学研究院 細胞治療内科学 石橋 亮一 他

EP-8 GH 補充はプラダー・ウィリー症候群の糖尿病発症頻度を低下させる

獨協医科大学越谷病院 小児科

独立行政法人国立成育医療研究センター 分子内分泌研究部／エコチル調査メディカルサポートセンター

綾部 匡之 他

EP-9＼cjkstart高血圧を契機に診断した再発性レニン産生卵管原発滑膜肉腫の 1 例

千葉大学医学部附属病院 糖尿病・代謝・内分泌内科

千葉大学大学院医学研究院 細胞治療内科学 橋本 直子 他

EP-10 ヒトでの新規膵 $\beta$ 細胞増殖蛋白ベータトロフィンと関連因子の検討

自治医科大学附属さいたま医療センター 内分泌代謝 山田 穂高 他 


\section{1月 28 日(金) $13: 15 \sim 14: 45$}

\section{3:15〜14:00下垂体 1／クッシング病 1}

\section{座長：松野 彰(帝京大学医学部 脳神経外科)}

P1-001 テモゾロミド治療を行った MGMT 陽性 ACTH 産生下垂体癌の一例

島根大学 医学部附属病院 卒後臨床研修センター 岡田 祐介

P1-002 肺癌原発の異所性 ACTH おょびカルシトニン産生腫瘍の一例

信州大学 医学部 内科学第 4 講座 樋渡 大 他

P1-003 糖尿病の悪化を契機に発見された異所性 ACTH 産生肺腫瘍の 1 例

独立行政法人国立病院機構 東京医療センター 内分泌内科

慶應義塾大学医学部 腎臟内分泌代謝内科 城 理絵 他

P1-004 異所性 ACTH 症候群を呈した胸腺発生大細胞神経内分泌癌の一例

岡山大学病院 内分泌センター／腎臟・糖尿病・内分泌内科 当真貴志雄 他

P1-005 異所性 ACTH 産生腫崵を呈した胸腺神経内分泌腫崵の一例 新潟県立中央病院 皆川 真一 他

\section{4:00〜14:45 下垂体 2/クッシング病 2}

\section{座長：鈴木(堀田) 眞理(政策研究大学院大学 保健管理センター)}

P1-006 （サブクリニカル)クッシング病が疑われた 5 例にみる診断の pitfall

国家公務員共済組合連合会 虎の門病院 内分泌代謝科荒井誠 他

P1-007 尿崩症で発見された Oncocytic type の ACTH 産生 macroadenoma の一例

千葉大学医学部付属病院 糖尿病代謝内分泌内科

千葉大学大学院医学研究院 細胞治療学 山本雅 他

P1-008 非典型な下垂体機能検査を示した囊胞性腺腫によるCushing 病の 1 例

三重大学医学部附属病院 糖尿病 - 内分泌内科 古田 範子 他

P1-009糖尿病バリスムを契機に診断された ACTH 産生下垂体腺腫の一例

済生会横浜市東部病院 糖尿病内分泌内科 大平 暁生 他

\section{3:15 14:00下垂体 3／先端巨大症 1}

\section{座長：田原 重志(日本医科大学 脳神経外科)}

P1-010 糖尿病加療中に発見された先端巨大症の検討

藤田保健衛生大学病院 内分泌代謝内科学 戸松 瑛介 他

P1-011 先端巨大症患者における QOL 調査

鹿児島大学 大学院 医歯学総合研究科 脳神経外科学 藤尾 信吾 他

P1-012 日本人先端巨大症患者における AcroQoL 日本語版の信頼性と有用性

神戸大学附属病院糖尿病 - 内分泌内科 吉田 健一 他

P1-013 下垂体卒中が疑われた GH 産生 microadenoma の一例 草加市立病院 内分泌代謝内科 芹澤 瑞穂 他

P1-014 手術・薬物療法に難渋し $\gamma$ ナイフが奏効した先端巨大症の一例

公立陶生病院 内分泌 - 代謝内科 富貴原 紗侑里 他 


\section{4:00 14:45下垂体 4／下垂体腫瘍 1}

座長：西岡 宏 (虎の門病院 内分泌センター 間脳下垂体外科)

P1-015＼cjkstart症候性ラトケ囊胞 3 例に打ける多彩な臨床症状と病態の比較

千葉大学医学部附属病院 糖尿病代謝内分泌内科

千葉大学医学部大学院医学系研究院 細胞治療内科学 小出 尚史 他

P1-016 ラトケ囊胞により一過性の汎下垂体機能低下・PMR を来たした一例

JA 愛知厚生連海南病院 糖尿病 - 内分泌内科 長谷川義高 他

P1-017 視床下部性下垂体前葉機能障害, 尿崩症を呈したラトケ囊胞の 2 症例

自治医科大学附属さいたま医療センター 内分泌代謝科 浅野 智子 他

P1-018ステロイドに反応し血清 IgG4 高値を呈したラトケ囊胞の一例

富士重工業健康保険組合 太田記念病院 内分泌内科 金指 秀明 他

P1-019 PLAP・超高感度 hCG- $\beta$ が診断に有用であった germinoma の一例

旭川医科大学 小児科 古谷 曜子 他

P1-020＼cjkstart両側卵巣腫揚を契機に診断された FSH 産生下垂体腺腫の 1 例

名古屋第一赤十字病院 内分泌内科 牛田 美帆 他

\section{3:15 14:00下垂体 5／下垂体機能低下症 1}

座長：大月 道夫(大阪大学大学院医学系研究科 内分泌・代謝内科)

P1-021 肝生検を施行した小児期発症 GH 分泌不全症 5 例の検討

神戸大学医学部附属病院 糖尿病内分泌内科 志智 大城 他

P1-022 成人 GHD における GH 補充の QOL 改善効果の検討 山形大学医学部附属病院 第三内科 羽田幸里香 他

P1-023 術後下垂体腺腫を伴う AGHDにGH 補充療法が有効であった一例

公益財団法人東京都保健医療公社＼cjkstart豊島病院 内分泌代謝内科 安東＼cjkstart環＼cjkstart他

P1-024 成人 GHD に対する GH 補充療法の QOL 改善効果を予測する因子の検討

日本イーライリリー株式会社 医学科学本部 岩本 紀之 他

P1-025 減量, 而糖能改善後 GH 分泌が改善した視床下部海綿状血管腫の一例

虎の門病院 内分泌代謝科 大和 梓 他

P1-026ステロイド投与後 GH 分泌不全が改善した下垂体機能低下症の 1 例

成田赤十字病院 糖尿病代謝内科 横山 三尚 他

\section{4:00～14:45 下垂体 6 /下垂体炎 1}

座長：清水 力(北海道大学病院 検査・輸血部)

P1-027 続発性副腎不全を契機に診断された IgG4 関連下垂体炎の 2 例

公立昭和病院 内分泌 - 代謝内科 金子 千束 他

P1-028 IgG4 関連下垂体炎が疑われた一例都大学 医学部 糖尿病内分泌栄養科 大野 洋一 他

P1-029＼cjkstart意識障害遷延を機に発見された IgG4 関連下垂体炎，大動脈炎合併例

北里大学医学部 内分泌代謝内科学 正木 嗣人 他

P1-030 下垂体後葉に限局した IgG4 関連下垂体炎の 1 例 虎の門病院内分泌代謝科 菊野 庄太 他

P1-031 後腹膜線維症を併発し、IgG4 関連下垂体炎と考えられる 1 例

自治医科大学 内分泌代謝科 高橋 学 他

P1-032 IgG4 関連下垂体炎との鑑別を要した多発性血管炎性肉芽腫症の一例

神戸大学 大学院医学研究科 糖尿病 - 内分泌内科学 坂東 弘教 他

P1-033 IgG4 関連自己免疫性膵炎に合併した、リンパ球性下垂体炎の 1 例

横浜市立大学附属市民総合医療センター 内分泌・糖尿病内科 渡辺 宏美 他 


\section{3:15 14:00 下垂体 7 / ADH 分泌異常症・電解質異常}

座長：高木 潤子(愛知医科大学医学部 内科学講座 内分泌・代謝内科)

P1-034＼cjkstart患者判断による水分制限が診断に役立った中枢性尿崩症の 1 例

兵庫県立加古川医療センター 総合内科 清家 雅子 他

P1-035 術後 3 週間目に突然尿崩症を発症した鞍結節部髄膜腫の一例

鹿児島大学 医学部 脳神経外科 羽生 未佳 他

P1-036 中枢性尿崩症と腎性尿崩症を合併した一例 筑波大学附属病院 内分泌代謝・糖尿病内科 村松 愛子 他

P1-037 多発血管炎性肉芽腫症(GPA)加療中に中枢性尿崩症を合併した一例

岡山大学病院 腎臓・糖尿病 - 内分泌内科 /内分泌センター 原 孝行 他

P1-038 発熱・低 Na 血症の原因評価が困難であった春䯣損傷受傷 8 年後の 1 例

慶應義塾大学 医学部 腎臓内分泌代謝内科 藤井千華子 他

P1-039 低ナトリウム血症の鑑別に難渋した一例 みさと健和病院 内科 小野寺晴子 他

P1-040 自己免疫性自律神経節障害が疑われた低 $\mathrm{Na}$ 血症の一例

東京女子医科大学八千代医療センター 糖尿病 - 内分泌代謝内科 荻野 淳 他

\section{4:00～14:45甲状腺 1 ／バセドウ病 1}

\section{座長：江本 直也(日本医科大学千葉北総病院 内分泌内科)}

P1-041 チアマゾールで発熱・肝障害を突発したバセドウ病・1 型糖尿病

帝京大学 医学部 内科学講座 根本かおり 他

P1-042 メチマゾール投与が原因となった再生不良性貧血の 1 例

独立行政法人 国立病院機構 仙台医療センター 内分泌代謝内科 桜井華奈子 他

P1-043 Basedow 病の 131I 内用療法における至適投与量の検討

国立病院機構京都医療センター 内分泌代謝内科 中谷理恵子 他

P1-044バセドウ眼症に ITP が合併しステロイドパルスが著効した 1 例

京都大学 医学部附属病院 糖尿病 - 内分泌・栄養内科 松尾 浩司 他

P1-045 バセドウ病を合併した機能性甲状腺癌の一例恶媛県立中央病院 総合診療科 玉木みずね 他

P1-046＼cjkstart経口不能な甲状腺機能立進症の短期間での術前のコントロール

奈良県立医科大学 消化器 - 内分泌代謝内科 田原 一樹 他

\section{3:15〜14:00甲状腺 2 ／バセドウ病 2}

\section{座長：宮川めぐみ(虎の門病院 内分泌代謝科)}

P1-047 心室頻拍から心停止したバセドウ病の 1 例

東京都立 多摩総合医療センター 内分泌代謝内科 川崎 元樹 他

P1-048 右下肢麻痺が遷延したバセドウ病若年男性の 1 例 福井大学 医学部 第 3 内科 藤井 美紀 他

P1-049＼cjkstart成人後発症した夜尿を契機に診断に至ったバセドウ病の一例

名古屋市立大学大学院 医学研究科 消化器 - 代謝内科学 蜂谷 真代 他

P1-050 バセドウ病で内服治療中、舞踏様の不随意運動で入院となった一例

埼玉医科大学総合医療センター 内分泌・糖尿病内科 秋山 義隆 他

P1-051 全身の重篤な筋力低下を来した甲状腺中毒性ミオパチーの 1 例

名古屋第二赤十字病院 糖尿病内分泌内科 栗本 隼樹 他

P1-052＼cjkstart潰瘍性大腸炎によりクリーゼの症状を呈したバセドウ病の一例

公益社団法人 鹿児島共済会 南風病院 内科 竹迫 慎平 他

P1-053 TRAb 陽性 TSAb 陰性 TSBAb 陰性を示す自己免疫性肝炎合併バセドウ病

草津総合病院 糖尿病 - 内分泌内科 鷲山 美樹 他 


\section{4:00 14:45甲状腺 3／甲状腺腫瘍・その他}

\section{座長：杉谷 巌(日本医科大学 内分泌外科学)}

P1-054 頝部腫大を契機に診断された甲状腺悪性リンパ腫の 2 例 聖路加国際病院内分泌代謝科 中川 朋子 他

P1-055＼cjkstart腺腫様結節と鑑別を要した甲状腺濾胞乳頭癌の一例

稲沢市民病院 糖尿病 - 内分泌内科 竹藤 聖子 他

P1-056＼cjkstart正中䅡囊胞として経過観察されていた好酸性細胞型滤胞癌の一例

東邦大学医学部 教育開発室／内科学講座 糖尿病 - 代謝 - 内分泌学分野 吉原 彩 他

P1-057 甲状腺機能充進診断に苦慮した治療抵抗性 Parkinson 合併の TSHoma

千葉大学医学部附属病院 糖尿病・代謝 - 内分泌内科

千葉大学大学院医学研究院 細胞治療内科学 駒井 絵里 他

P1-058 TSH 産生腫瘍の一例

横浜市立みなと赤十字病院 澤井 瑞貴 他

\section{3:15 14:00＼cjkstart副腎 1 /クッシング症候群 1}

座長：上芝 元(東邦大学医学部 内科学 糖尿病・代謝・内分泌学分野)

P1-059 胸腰椎多発圧迫骨折で診断された副腎性クッシング症候群の 1 例

$\mathrm{JCHO}$ 東京新宿メディカルセンター 内科 板谷 美穂 他

P1-060 局在診断に苦慮した両側副腎腫瘍合併クッシング症候群の一例

兵庫県立加古川医療センター 糖尿病 - 内分泌内科 中村 幸子 他

P1-061 下垂体腫大を契機に発見された副腎腺腫性クッシング症候群の一例

北里大学 医学部 内分泌代謝内科学 鈴木 陽彦 他

P1-062 低血糖症が初発の副腎性周期性クッシング症候群と考えられた一例

順天堂大学大学院 代謝内分泌内科学 鈴木瑠璃子 他

P1-063 Cushing 症候群を呈した巨大石灰化を伴う副腎 black adenoma の一例

トヨ夕記念病院 内分泌科 加藤 二郎 他

\section{4:00〜14:45＼cjkstart副䁂 2/クッシング症候群 2}

座長：齊藤 智之(自治医科大学附属さいたま医療センター 内分泌代謝科)

P1-064 片側副腎摘出 9 年後に対側副腎腫瘍を指摘されたPA 合併 SCS の 1 例

市立札幌病院 糖尿病 - 内分泌内科 和田 典男 他

P1-065 術後に心機能が改善したサブクリニカルクッシング症候群の 1 例

神戸大学大学院 医学研究科 糖尿病 - 内分泌内科学 隅田健太郎 他

P1-066 異所性ホルモン受容体発現が示唆された家族性 AIMAH の二例

横浜市立大学附属病院 内分泌・糖尿病内科 國下梨枝子 他

P1-067 異所性受容体と steroid 産生の異なる表現型を示した家族性 AIMAH

千葉大学医学部附属病院 糖尿病代謝内分泌内科

千葉大学大学院医学研究院 細胞治療内科学 馬場 雄介他

\section{3:15 14:00 副腎 3／副腎腫瘍}

座長：菊森 豊根(名古屋大学医学部附属病院 乳腺・内分泌外科)

P1-068 無月経を機に副腎癌と診断され術後 4 年で健常児を出産し得た一例

富山県立中央病院 内科 (内分泌 - 代謝) 加藤健一郎 他

P1-069 副腎皮質癌術後に腫瘍床放射線照射した一例

P1-070 高齢発症の副腎原発 Ewing 肉腫の一例
浜松医科大学 第二内科 黒田 豪 他 群馬大学 医学部 病態制御内科 石井 角保 他 
P1-071 メトトレキサート関連リンパ増殖性疾患による両側副腎腫瘍の 1 例

金沢大学附属病院 臟器機能制御学 内分泌代謝内科 森 俊介他

P1-072 副腎腫瘍における PET/CT の有用性の検討

$$
\text { 弘前大学 大学院医学研究科 内分泌代謝内科学 浅利ゆう子 他 }
$$

P1-073 術前診断に苦慮した副腎部脱分化型脂肪肉腫の一例

岡山大学病院 腎臓・糖尿病 - 内分泌内科/内分泌センター 細谷 武史 他

\section{4:00 14:45 副腎 4/原発性アルドステロン症 1}

\section{座長：佐藤 文俊(東北大学病院 腎・高血圧・内分泌科)}

P1-074 重症心不全を合併した原発性アルドステロン症の 1 例

金沢大学 医学部 臓器機能制御学 青野 大輔 他

P1-075 副腎腫瘍にアルドステロン・コルチゾール自律性分泌を伴った一例

兵庫県立加古川医療センター 糖尿病 - 内分泌内科 生天目侑子 他

P1-076 両側性原発性アルドステロン症に SCS を合併した 1 例

横浜市立 みなと赤十字病院 糖尿病内分泌代謝内科 加計 剛 他

P1-077 妊娠中に診断・治療し分婏に至った原発性アルドステロン症の一例

北海道大学 内科 2 橋本 玲奈 他

P1-078 アルドステロン過剩分泌の心合併症への影響

広島大学 大学院 医歯薬保険学研究科 分子内科学講座 岸本 瑠衣 他

P1-079 アルドステロン産生副腎皮質癌の 1 例

北海道厚生連 札幌厚生病院 森 孝之 他

\section{3:15 14:00＼cjkstart副腎 5／褐色細胞腫 1}

\section{座長: 竹越 一博 (筑波大学医学医療系臨床医学域)}

P1-080 先端巨大症に合併した褐色細胞腫の一例埼玉医科大学病院 内分泌糖尿病内科 井内卓次郎 他

P1-081 サブクリニカルクッシング症候群を合併した褐色細胞腫の一例

近畿大学 医学部 内分泌 - 代謝 - 糖尿病内科 吉田 左和 他

P1-082 同側副腎に個別に非機能性腺腫と褐色細胞腫を合併した 1 例

天理よろづ相談所病院 内分泌内科 飯降 直男 他

P1-083 産裖期に診断された褐色細胞腫の一例 和歌山県立医科大学 医学部 第一内科 太田 敬之 他

P1-084 当科で経験した褐色細胞腫 3 例の検討

独立行政法人 国立病院機構 姫路医療センター 内科 畑尾満佐子 他

\section{4:00～14:45 副腎 6／褐色細胞腫 2}

座長：臼井健(国立病院機構京都医療センター 臨床研究センター)

P1-085 巨大な頭蓋骨転移を伴った悪性パラガングリオーマの一例

つがる総合病院 内分泌・糖尿病・代謝内科

青森県立中央病院 内分泌内科 川嶋 詳子 他

P1-086 ラトケ襄胞、下垂体腺腫にパラガングリオーマを合併した一例

金沢大学 医薬保健研究域医学系 恒常性制御学 小川あゆみ 他

P1-087 腎動脈狭窄を合併した後腹膜原発パラガングリオーマの一例 富山赤十字病院 内科若林祐介他

P1-088 膀胱褐色細胞腫の 3例倉敷中央病院 内分泌代謝・リウマチ内科 山田倫子 他

P1-089 単心室症に副腎外褐色細胞腫を合併した一例

岡山大学病院 腎臟・糖尿病・内分泌内科／内分泌センター 小松原基志 他

P1-090 クロニジン負荷試験陽性であった偽性褐色細胞腫の 1 例 


\section{3:15 14:00＼cjkstart糖代謝 $1 ／ 1$ 型糖尿病・DKA}

座長：山田祐一郎(秋田大学大学院医学系研究科 内分泌・代謝・老年内科学)

P1-091ＤKA で発症し敗血症性肺塞栓症を合併した 1 型糖尿病の 1 例

東京医科大学八王子医療センター 糖尿病・内分泌・代謝内科 永田 卓美 他

P1-092＼cjkstart潰瘍性大腸炎と自己免疫性肝炎の既往に慢性甲状腺炎之

1 型糖尿病を発症した多腺性自己免疫症候群の一例済生会小樽病院 内科 水越 常徳 他

P1-093＼cjkstart進行肺腺癌に伴い原因不明の低血糖発作が生じた 1 型糖尿病の一例

兵庫県立尼崎病院 糖尿病 - 内分泌内科 細川 友誠 他

P1-094 清涼飲料水ケトーシスで発症し経過良好な肥満 1 型糖尿病の 1 例

青梅市立総合病院 内分泌糖尿病内科 関口 芳弘 他

P1-095 急性 E 型肝炎を合併した糖尿病性ケトアシドーシスの一例 埼玉石心会病院 内科 大和田里奈 他

P1-096＼cjkstart高 TG 血症にて偽性低 Na 血症を来した糖尿病ケトアシドーシスの一例

聖隷浜松病院 内分泌内科 井本 正樹 他

P1-097＼cjkstart静脈血栓塞栓症を合併した糖尿病性ケトアシドーシスの 1 例

帝京大学ちば総合医療センター 第三内科 平野 順子 他

\section{4:00 14:45＼cjkstart糖代謝 2／2型糖尿病・ステロイド糖尿病}

座長：小川 佳宏(東京医科歯科大学 糖尿病・内分泌・代謝内科)

P1-098２型糖尿病患者における虚血性心疾患予測に関するバイオマーカー

関東労災病院 糖尿病・内分泌内科 郷内めぐみ 他

P1-099 ICTP 高值を示した若年 2 型糖尿病の一例 地方独立行政法人 徳島県鳴門病院 内科 藤中 雄一 他

P1-100 不随意運動を契機に発見された糖尿病

埼玉医科大学病院 内分泌糖尿病内科 齊藤 太吾 他

P1-101 ステロイド糖尿病に膵島細胞症の合併が疑われた一例

順天堂大学大学院 医学研究科 代謝内分泌内科学 西尾 理恵 他

P1-102 著明な筋力低下と糖尿病を合併した医原性 Cushing 症候群の一例

帝京大学ちば総合医療センター 第 3 内科 渡部 玲子 他

\section{3:15 14:00 性腺 1}

\section{座長：緒方 勤(浜松医科大学 小児科学講座)}

P1-103 胸部 XP から疑い遺伝カウンセリングした Klinefelter 症候群の一例

東京大学 医学部 附属病院 腎臟 - 内分泌内科 高橋 克敏 他

P1-104 成長ホルモン分泌不全合併した成人 Klinefelter 症候群の 1 例

国立長寿医療研究センター 内分泌代謝内科 谷川 隆久 他

P1-105 肥満糖尿病患者で成人になり Turner 症候群と診断し得た一例

大分大学 医学部 内分泌代謝 - 膠原病 - 腎臟内科学講座 吉田 雄一 他

P1-106 Turner 症候群と CAH の合併を認めた副腎偶発腫の一例

神戸大学医学部附属病院 糖尿病 - 内分泌内科 岩橋 泰幸 他

\section{4:00 14:45＼cjkstart糖代謝 3／インスリノーマ 1}

座長：植木浩二郎(東京大学医学部 糖尿病・代謝内科 分子糖尿病科学講座)

P1-107 OGTT で0 分 IRI:1.2 - 30 分 3446 $\mu \mathrm{u} / \mathrm{ml}$ を示したインスリノーマの 1 例

菊名記念病院 糖尿病・内分泌内科 / 総合診療部

横浜市立大学大学院 分子内分泌 - 糖尿病内科学 百木 忠久 他 
P1-108 当院 13 年間のインスリノーマ正診率に与える低血糖症状の検討

東邦大学医学部内科学講座 糖尿病 - 代謝 - 内分泌学分野 (大森) 金口 桃子 他

P1-109 周術期の血糖管理に難渋したインスリノーマの 1 例

千葉大学大学院医学研究院 細胞治療内科学

千葉大学医学部附属病院 糖尿病 - 代謝内分泌内科 小林 明菜 他

P1-110 グルコース反応性インスリノーマの一例 草加市立病院 内分泌・代謝内科 小澤 直子 他

P1-111＼cjkstart高インスリン血症を伴い診断に苦慮した視床下部性副腎不全の一例

富士市立中央病院 代謝 - 一般内科

東京慈恵会医科大学附属病院 糖尿病 - 代謝 - 内分泌内科 星野 慈 他

P1-112＼cjkstart視床下部性副腎機能低下を合併したインスリノーマの 1 例

新潟大学医歯学総合病院 血液 - 内分泌 - 代謝内科 福武 嶺一 他

\section{3:15 14:00 小児内分泌}

座長：堀川 玲子(国立成育医療研究センター 内分泌代謝科)

P1-113 著明な成長障害を伴った腎性尿崩症の一例

福岡市立こども病院・感染症センター 内分泌代謝科 江藤 潤也 他

P1-114 中枢性性腺機能低下症を伴ったSOX10 異常によるWaardenburg 症候群

P1-115 46,XX/46,XY の核型を持つ性分化疾患の性染色体と性腺組織の関連 埼玉医科大学病院 小児科 武者 育麻 他

東京都保健医療公社 多摩北部医療センター

東京都立小児総合医療センター 内分泌 - 代謝科 仁科 範子 他

P1-116 軟骨無形成症及び軟骨低形成症に対する治療効果についての検討

国立成育医療研究センター 内分泌代謝科 菅原 大輔 他

P1-117 過成長、骨年齢促進を呈した乳幼児期発症バセドウ病の 2 例

新潟県済生会三条病院 小児科 佐々木 直 他

P1-118 肝障害、脂質異常を指摘され診断に至った萎縮性甲状腺炎の 1 例

埼玉県立小児医療センター 代謝 - 内分泌科 和氣 英一 他

P1-119 ACTH 不応症 (GC 単独欠損)の臨床像を示す NR0B1 変異陽性兄弟例

浜松医科大学 小児科学講座 大高幸之助 他

\section{4:00 14:45 肥満・摂食障害}

座長: 野牛 宏晃(筑波大学附属病院水戸地域医療教育センター内分泌代謝・糖尿病内科)

P1-120 成人期 Prader-Willi 症候群に対する糖尿病治療薬の検討

群馬大学 大学院医学系研究科 病態制御内科学 松本 俊一他

P1-121 耐糖能異常を認めた Prader-Willi 症候群の 5 症例

大阪府立母子保健総合医療センター 消化器 - 内分泌科 小西 絢子 他

P1-122 幼览肥満の長期経過 獨協医科大学 小児科 吉田 彩子 他

P1-123 当院での減量手術前後における体組成・代謝変動の追跡調査

東邦大学医療センター佐倉病院 糖尿病内分泌代謝センター 山口崇 他

P1-124 Refeeding 症候群を来したと考えられる摂食障害の 1 例

日本赤十字社医療センター 糖尿病内分泌科 高屋 和彦 他 


\section{3:15～14:00＼cjkstart骨カルシウム代謝 $1 ／$ 原発性副甲状腺機能穴進症 1}

\section{座長：田口学(東京大学医学部附属病院 腎臓内分泌内科)}

P1-125＼cjkstart本態性血小板血症を伴った原発性副甲状腺機能光進症の一例

稲沢市民病院糖尿病・内分泌内科 野村 由夫 他

P1-126下垂体副腎腫瘍合併副甲状腺癌を疑った原発性副甲状腺機能光進症

P1-127 巨大副甲状腺霅胞性病変による原発性副甲状腺機能立進症の一例 北海道大学病院 内科 II 宮 愛香 他 トヨ夕記念病院 内分泌科 宮田崇 他

P1-128 急激な血糖上昇に併発した原発性副甲状腺機能九進症の 1 例 兵庫県立加古川医療センター 総合内科 石田 育大 他

P1-129 意識障害を契機に発見された原発性副甲状腺機能九進症の一例

東京女子医科大学病院 高血圧 - 内分泌内科 高野 倫嘉 他

\section{4:00 14:45 骨カルシウム代謝 2／原発性副甲状腺機能六進症 2 ・高カルシウム血症}

座長：難波 範行 (大阪大学大学院医学系研究科 小児科学)

P1-130 シナカルセト内服にて加療した原発性副甲状腺機能立進症の 2 例

自治医科大学 医学部 内分泌代謝学部門 齋藤 新介 他

P1-131 原発性副甲状腺機能立進症におけるシナカルセトの効果の検討

神戸大学医学部附属病院 糖尿病 - 内分泌内科 末松 那都 他

P1-132 原発性副甲状腺機能立進症におけるデノスマブの効果の検討

神戸大学医学部付属病院 糖尿病 - 内分泌内科 山田 佳子 他

P1-133 複数の病態の関与が考えられた高 $\mathrm{Ca}$ 血症の 1 例 北里大学メディカルセンター 海瀬 綾子 他

\section{3:15 14:00 研修医・学生部門 /糖尿病・低血糖} 座長：石橋 俊(自治医科大学 内科学講座 内分泌代謝科)

P1-134 神経繊維腫症 1 型に合併し季節的変動を呈した 1 型糖尿病 群馬大学医学部附属病院 岡田 純一 他

P1-135 多様な自己免疫疾患を併発した多腺性自己免疫症候群 3 型の 1 例

東京女子医科大学 卒後臨床研修センター／糖尿病センター内科 河合 悠里 他

P1-136＼cjkstart抗インスリン抗体陽性のインスリン受容体異常症 B 型の 1 例

$$
\text { 川崎医科大学 卒後臨床研修センター 菅勇貴 他 }
$$

P1-137＼cjkstart術前後に糖負荷試験で膵島機能の評価をしたインスリノーマの 1 例

公益財団法人 田附興風会 医学研究所 北野病院 黒田 彩子 他

P1-138 CGM にてオクトレオチドの効果を確認した高齢インスリノーマの 1 例

千葉市立青葉病院 内科 宮地 秀明 他

P1-139 ジアゾキサイド中止時期の検討に CGMS が有用であった 1 例

新潟大学医歯学総合病院 総合臨床研修センター 村井英四郎 他

P1-140ＣGM によりシタグリプチンの効果を確認できた反応性低血糖の一例

岡山済生会総合病院 内科 角南 良太 他

\section{4:00 14:45 研修医・学生部門／下垂体 1 (先端巨大症・TSH 産生下垂体腫瘍)}

座長：三木 伸泰(新百合ヶ丘総合病院 内分泌代謝内科)

P1-141 ACTH 過剩産生を伴った先端巨大症の 1例＼cjkstart高知大学医学部 卒後臨床研修センター 杉浦 健太 他 P1-142 うっ血性心不全発症を契機に診断に至った先端巨大症の一例 
P1-143 門脈大循環シャント塞栓術後に IGF-1 が上昇した先端巨大症の 1 例

P1-144 TSH 産生腫瘍、脳塞栓症と抗体陰性のバセドウ病を合併した 1 例

福井県立病院 内分泌代謝科 高橋 芳徳 他

日本医科大学付属病院 糖尿病 - 内分泌代謝内科 梶尾 円香 他

P1-145 無痛性甲状腺炎との鑑別を要した TSH 産生腫瘍の 1 例

東京女子医科大学 高血圧 - 内分泌内科 松林 麻里 他

P1-146 オクトレオチドが奏効した心不全・腎不全合併 TSH 産生腫瘍の一例

静岡県立総合病院 糖尿病 - 内分泌内科 嘉藤 光歩 他

\section{3:15 14:00 研修医・学生部門 /甲状腺}

座長：佐藤 哲郎(群馬大学医学部附属病院 内分泌糖尿病内科)

P1-147 妊娠初期に PTU 耐性となり MMI と KI 併用療法を要したバセドウ病

東邦大学医学部医学科内科学講座糖尿病 - 代謝 - 内分泌学分野 西宮 哲生 他

P1-148 肺炎加療にて入院後に発症し救命し得た甲状腺クリーゼの一例

大阪市立総合医療センター 内分泌内科橋村朋 他

P1-149 下垂体機能低下を伴う無痛性甲状腺炎による甲状腺クリーゼの一例

大阪府済生会中津病院 高瀬 真吾 他

P1-150 非代償性肝硬変での意識障害が甲状腺機能低下症で起こった一例

社会医療法人 愛仁会 千船病院 内科 金岡 由起 他

P1-151 甲状腺機能低下症をきっかけに下垂体腫大が発見された一例

国立病院機構 呉医療センター 内分泌 - 糖尿病内科 川田 哲史 他

P1-152 高血圧を契機に発見された阻害型 TRAb 陽性甲状腺機能低下の一例

東京女子医科大学 高血圧内分泌内科 松井 聡子 他

P1-153 血流障害の関与が疑われた薬剂性甲状腺機能低下症の一例

山梨大学 医学部 第三内科 杉山 佳子 他

\section{4:00 14:45 研修医・学生部門／下垂体 2 (ワッシング病・その他)}

座長：金本 巨哲(大阪市立総合医療センター 内分泌内科)

P1-154 初診時 ACTH 正常にて専門医受診に至らなかったクッシング病の一例

鳥取大学医学部附属病院 卒後臨床研修センター 北尾 苑子 他

P1-155 大分子型 ACTH 産生下垂体腫瘍による subclinical Cushing 病の 1 例

大阪市立総合医療センター 内分泌内科 吉岡茉依子 他

P1-156 DDAVP 試験で ACTH、F が抑制された偽性クッシング症候群の 2 例

島根大学医学部附属病院 卒後臨床研修センター 木村 綾乃 他

P1-157 副腎偶発腫瘍を併発したクッシング病の 1 例 公立富岡総合病院 内科 櫻井みずき 他

P1-158 TMZ 治療後に高い増殖能で再発した異型性下垂体腺腫の一例

島根大学 医学部 内科学講座 内科学第一 奥村 信人 他

P1-159 低 Na 血症と視神経春髄炎関連疾患を合併した一例

日本医科大学 付属病院 糖尿病 - 内分泌代謝内科 中山 幸治 他 


\section{1月 29 日(土) $13: 15 \sim 14: 45$}

\section{3:15〜14:00下垂体 8 /クッシング病 3}

座長：在原 善英(仙台医療センター 内分泌代謝内科)

P2-001 ACTH、GH 同時産生下垂体腺腫の一例

東京女子医科大学 内科学(第二)講座 (高血圧 - 内分泌内科) 竜崎 正毅 他

P2-002 巨大下垂体腺腫を呈した顕性・不顕性クッシング病 2 例の比較検討

千葉大学医学部付属病院 糖尿病代謝内分泌内科

千葉大学大学院医学研究院 細胞治療学 志賀 明菜 他

P2-003＼cjkstart血糖管理の視点からの難治性クッシング病治療の比較検討

千葉大学医学部附属病院 糖尿病 - 代謝 - 内分泌内科

千葉大学大学院 細胞治療内科学 佐久間一基 他

P2-004 両側副腎摘出術を施行した難治性クッシング病の一例

大阪大学大学院 医学系研究科 内分泌 - 代謝内科学 高比康充 他

P2-005 骨粗鬆症を契機に診断され，術後に骨密度が著明改善した Cushing 病

自治医科大学 附属さいたま医療センター 内分泌代謝科 生駒 亜希 他

\section{4:00 14:45下垂体 9 /先端巨大症 2}

\section{座長：杉原仁(日本医科大学大学院医学研究科 内分泌糖尿病代謝内科学)}

P2-006 中毒性多結節性甲状腺腫を合併した先端巨大症の一例

和歌山県立医科大学 内科学第一講座 浦木 進丞 他

国立循環器病センター 肥塚諒 他

P2-008 McCune-Albright 症候群に伴う薬物治療に抵抗性の先端巨大症の 1 例 虎の門病院 内分泌代謝科 林 恭秉 他

P2-009 ランレオチドを術前投与した GH・TSH 産生下垂体腺腫の一例

筑波大学附属病院 内分泌代謝 - 糖尿病内科 志鎌 明人 他

P2-010＼cjkstart腫瘍組織に神経節細胞腫を含む偶発 GH 産生腺腫 PANCH の一例

新百合ヶ丘総合病院 内分泌代謝科 小野 昌美 他

\section{3:15～14:00下垂体10／下垂体腫瘍 2 ・その他} 座長：小野 昌美(新百合ヶ丘総合病院 内分泌代謝)

P2-011 TSH 産生下垂体腺腫の手術後に TRAb 陰性バセドウ病を発症した 1 例 順天堂大学大学院 代謝内分泌内科学 増山 敦 他

P2-012＼cjkstart灰白隆起周辺に限局した腫瘤性病変による下垂体機能低下症の一例

名古屋掖済会病院 糖尿病・内分泌内科 吉田 昌則 他

P2-013 高プロラクチン血症の加療に伴いインスリン抵抗性が改善した 1 例

国立病院機構 鹿児島医療センター 糖尿病・内分泌内科 小木曽和磨 他

P2-014ＴRH を除いた三者刺激試施行中に発症した下垂体卒中の 1 例

東京医科歯科大学大学院分子内分泌代謝学(糖尿病 - 内分泌 - 代謝内科) 西谷 里枝 他

P2-015 下垂体腫大が遷延し ITT で低反応を認めた橋本病の 1 例 京都市立病院 内分泌内科 筫谷 雄二 他 


\section{4:00 14:45 下垂体11／下垂体機能低下症 2}

\section{座長：西山充(高知大学医学部 内分泌代謝・腎臓内科)}

P2-016 未発症 1 型糖尿病と汎下垂体機能低下症を合併した APS3 型の一例

北播磨総合医療センター 糖尿病 - 内分泌内科 竹内 健人 他

P2-017 放射線治療 24 年後に診断された視床下部性下垂体機能低下症の 1 例

自治医科大学附属さいたま医療センター 内分泌代謝科 浅野 智子 他

P2-018 心肺蘇生後に発症した中枢性尿崩症と下垂体前葉機能低下症の一例

国立病院機構 名古屋医療センター 糖尿病 - 内分泌内科 曹 霞 他

P2-019 下垂体腫瘍・下垂体機能低下症にたこつぼ型心筋症を合併した 1 例

弘前大学医学部附属病院 内分泌代謝内科 村澤 真吾 他

P2-020 たこつぼ型心筋症により心停止に至った汎下垂体機能低下症の一例

仙台医療センター 内分泌代謝内科 在原 善英 他

P2-021 偽後葉を合併した部分的下垂体前葉機能低下症の一例

島根大学 医学部 内科学講座 内科学第一 横本 真希 他

\section{3:15 14:00下垂体12/下垂体機能低下症 3}

\section{座長：菅原 明(東北大学大学院医学系研究科 分子内分泌学分野)}

P2-022 重症貧血及び著明なるいそうを認めた ACTH 単独欠損症の 1 例

兵庫県立西宮病院 内科 山本 研人 他

P2-023 薬剤性 ACTH 分泌低下症が疑われた一例 徳島大学病院 内分泌代謝内科 大黒由加里 他

P2-024 HPA 日内変動の時相調整が有効であった 1 例

九州大学大学院 医学研究院 病態制御内科学 仲山 倫子 他

P2-025 難聴、大脳白質病変、尿細管障害を合併した性腺機能低下症の一例

静岡県立総合病院 糖尿病 - 内分泌内科 佐藤 友理 他

P2-026 骨粗鬆症による骨折を契機に診断された Kallmann 症候群の一例

成田赤十字病院 総合内科 森尾比呂志 他

P2-027頭部 MRI 検査にて異所性下垂体後葉を認めた 3 例

大阪大学大学院 医学系研究科 小児科学 小西 暁子 他

\section{4:00 14:45 下垂体13/下垂体资 2}

\section{座長：福田いずみ(東京女子医科大学 高血圧・内分泌内科)}

P2-028 妊娠中に発症したリンパ球性下垂体炎の 2 例

富山大学 医学部 第一内科 中嶋 歩 他

P2-029 リンパ球性下垂体炎による汎下垂体機能低下症治療後の自然妊娠例

自治医大さいたま医療センター 代謝内分泌科 船崎 俊介 他

P2-030 少量ステロイドで下垂体縮小を認めたリンパ球性汎下垂体炎の 1 例

P2-031 ステロイド療法を施行した肥厚性硬膜炎、下垂体炎の一例

市立砺波総合病院 内分泌内科 早川 哲雄 他

北里大学医学部 内分泌代謝学 高井久仁庸 他

P2-032 下垂体前葉機能の急激な低下をきたした漏斗下垂体後葉炎の一例

NTT 東日本札幌病院 糖尿病内分泌内科 平田恵里奈 他

P2-033 中枢性尿崩症及び渇中枢障害を呈した視床下部下垂体炎の一例

旭川医科大学 内科学講座 病態代謝内科学分野 中村 知伸 他

P2-034 診断に苦慮した低 $\mathrm{Na}$ 血症の一例

独立行政法人 国立病院機構 仙台医療センター 内分泌 - 代謝内科 山下 りか 他 


\section{3:15 14:00甲状腺 4／その他の甲状腺機能六進症}

座長：久保田 憲(がん感染症センター都立駒込病院 糖尿病・内分泌内科)

P2-035 亜急性甲状腺炎 15 症例の検討 箕面市立病院糖尿病センター 津川 有理 他

P2-036 少量 PSL で疼痛消失後急速気道狭窄を生じた Riedel 甲状腺炎の一例

多摩北部医療センター 内分泌代謝内科 藤田 寛子 他

P2-037＼cjkstart呼吸停止を来し甲状腺全摘を要した AIT2 型の一例

横浜労災病院 内分泌糖尿病センター 三木 郁 他

P2-038＼cjkstart無機ヨードでコントロールした中毒性多結節性甲状腺腫

東邦大学 医学部 内科学講座 糖尿病 - 代謝 - 内分泌学分野 鴫山 文華 他

\section{4:00 14:45 甲状腺 5 /甲状腺機能低下症}

座長：大塚 史子(昭和大学藤が丘病院 内分泌代謝科)

P2-039 橋本病に合併した重症甲状腺眼症の高齢男性

勤医協中央病院 糖尿病内分泌 - 腎臓病センター 加藤 友美 他

P2-040 大量腹水および CA125 上昇を合併した甲状腺機能低下症の一例

国立病院機構 天竜病院 内分泌代謝内科 池谷 章 他

P2-041甲状腺機能低下症発症により、心囊液貯留にまで至った 1 例

獨協医科大学越谷病院 糖尿病内分泌 - 血液内科 寺沢 智子 他

P2-042 甲状腺無・低形成と中枢性甲状腺機能低下症における FT3／FT4 比

神奈川県立こども医療センター 内分泌代謝科 大戸 佑二 他

P2-043＼cjkstart多彩な内分泌異常を認めた POEMS 症候群の 1 例

東京慈恵会医科大学 葛飾医療センター 総合内科 井坂 剛 他

\section{3:15〜14:00＼cjkstart副腎7/クッシング症候群 3}

座長：草鹿 育代(自治医科大学附属さいたま医療センター 内分泌代謝科)

P2-044 クッシング症候群術後の甲状腺機能立進症の臨床経過

大阪大学 大学院医学系研究科 内分泌 - 代謝内科 村田 雅彦 他

P2-045 副腎性 Cushing 症候群と PA を合併した GAD 抗体陽性糖尿病の 1 例

公立甲賀病院 内科 大村 寧 他

P2-046 コルチゾールの過剰分泌を呈した副腎悪性リンパ腫の一例

弘前大学 医学部 附属病院 内分泌代謝内科 中田 有紀 他

P2-047 画像上 AIMAH が疑われたが、内分泌学的異常を指摘できない 1 例

大阪府済生会中津病院 糖尿病内分泌内科 山内 一郎 他

\section{4:00 14:45 副腎 8 / Gitelman 症候群・副腎出血}

\section{座長：鈴木 洋通(埼玉医科大学 腎臓内科)}

P2-048＼cjkstart遺伝子診断により確定診断し得た Gitelman 症候群の 1 例

東京都立多摩総合医療センター 内分泌代謝内科 平澤 麗子 他

P2-049 低 K 血症をきたしクリアランス試験で診断した Gitelman 症候群の 1 例

NTT 東日本札幌病院 糖尿病内分泌代謝内科 大森 一乃 他

P2-050 利尿薬負荷後に結晶誘発性関節炎を発症した Gitelman 症候群の 1 例

弘前大学医学部附属病院 内分泌内科 - 糖尿病代謝内科 - 感染症科 石亀 敬子 他

P2-051 抗リン脂質抗体症候群を背景に両側副腎出血を呈した一例 
P2-0529年間で緩徐に増大し腫瘍との鑑別に苦慮した副腎血腫の 1 例

兵庫県立加古川医療センター 総合内科 藤田 泰功 他

P2-053 肺炎球菌による Waterhouse-Friderichsen 症候群の 1 例

平塚市民病院 飯ヶ谷嘉門 他

P2-054 補充療法で多血症が改善した 21 水酸化酵素欠損症の一男性例

神戸大学医学部附属病院 糖尿病内分泌内科 西澤 衡 他

\section{3:15 14:00 副腎 9 /副腎皮質機能低下症・その他}

\section{座長：七里 眞義(北里大学医学部 内分泌代謝内科学)}

P2-055 肝硬変に合併した低コルチゾール血症の 2 例

弘前大学 医学部附属病院 内分泌代謝内科 山下 真紀 他

P2-056 副腎不全を契機に診断されたAdrenomyeloneuropathy(AMN)の 1 例

岐阜大学医学部附属病院 免疫内分泌内科 藤澤 太郎 他

P2-057 認知症の進行により副腎不全管理に難渋した 1 例国際医療福祉大学熱海病院 平馬誠之 他

P2-058 低用量・高用量迅速 ACTH 逐次負荷試験の妥当性についての検討

労働者健康福祉機構 東京労災病院 糖尿病 - 内分泌内科 桑原公一郎 他

P2-059 遺伝性尿細管症候群が疑われ治療に難渋する低力リウム血症の一例

順天堂大学大学院代謝内分泌内科学 氷室 美和 他

P2-060 家族性偽性高カリウム血症の一家系名古屋掖済会病院 糖尿病 - 内分泌内科 福岡 一貴 他

P2-061両側副腎摘出術後に晚発性に低 $\mathrm{Na}$ 血症を来した一例

東京女子医科大学 内科学(第二)講座 (高血压 - 内分泌内科) 竜崎 正毅 他

\section{4:00 14:45＼cjkstart副腎10／原発性アルドステロン症 2}

\section{座長：寺田 典生 (高知大学医学部 内分泌代謝・腎臓内科学教室)}

P2-062 ACTH 試験は APA 診断に有用だが両側病変/本態性高血圧の鑑別は困難

松波総合病院 内科 山田 梨絵 他

P2-063 原発性アルドステロン症診断における血漿レニン濃度の有用性

東北大学病院 腎・高血圧 - 内分泌科 小野 美澄 他

P2-064 原発性アルドステロン症の腎障害における尿バイオマーカーの解析

東北大学病院 腎・高血圧 - 内分泌科 岩倉 芳倫 他

P2-065 アルドステロン絶対值を考慮したPA の一次スクリーニング

広島大学大学院 医歯薬保健学研究科分子内科学 沖健司他

P2-066 APA とAPCC 共存 KCNJ5 陽性原発性アルドステロン症

横浜労災病院 内分泌糖尿病センター 田村 愛 他

\section{3:15 14:00＼cjkstart副腎11／原発性アルドステロン症 3}

\section{座長：齋藤 淳(横浜労災病院 内分泌糖尿病センター)}

P2-067 当施設で実施した CT ガイド下 S-AVS/SS-AVS(203 例)の後方視的検討

千葉大学大学院医学研究院 細胞治療内科学

千葉大学医学部附属病院 糖尿病代謝内分泌内科 永野 秀和 他

P2-068 傍副腎アルドステロン腺腫の 1 例：サンプリング診断の盲点

金沢医科大学 糖尿病 - 内分泌内科渡邊 愛 他

P2-069 原発性アルドステロン症の術後治癒とAVS 判定基準の関連

国立病院機構 京都医療センター 内分泌代謝高血圧研究部 馬越 洋宜 他

P2-070 ACTH負荷 AVS における contralateral ratio の意義 
P2-071 AVS 判定基準による原発性アルドステロン症病型診断の比較

済生会横浜市東部病院 糖尿病 - 内分泌内科 一城 貴政 他

P2-072 選択的副腎分葉内支脈採血診断に基づく低侵襲性副腎部分切除

横浜労災病院 内分泌・糖尿病センター 中島 薰 他

\section{4:00 14:45 副腎12／褐色細胞腫 3}

\section{座長：橋本 重厚(福島県立医科大学 放射線医学県民健康管理センター)}

P2-073 片側低形成腎に合併したカテコラミン産生腫瘍の 1 例

岡山大学病院 腎臓・糖尿病 - 内分泌内科 / 総合内科 寺坂 友博 他

P2-074 家族性褐色細胞腫が疑われ両側副腎に褐色細胞腫を認めた一例

自治医科大学附属病院 内分泌代謝科 岡野 義英 他

P2-075 急速増大を認めた悪性褐色細胞腫に対し CVD 療法が奏功した 1 例

聖マリアンナ医科大学 横浜市西部病院 代謝 - 内分泌内科 佐々木要輔 他

P2-076 多発骨髄転移を伴う IL-6 産生性 MPC での集学的治療経過と剖検所見

千葉大学 医学部附属病院 糖尿病 - 代謝 - 内分泌内科 滝口 朋子 他

P2-077 両側褐色細胞腫における癌抑制遺伝子コピー数とエピゲノム解析

国立病院機構京都医療センター 内分泌 - 代謝内科 廣田 圭昭 他

P2-078 難治性便秘を呈した SDHB 遺伝子変異による悪性褐色細胞腫の一例

名古屋大学医学部附属病院 糖尿病 - 内分泌内科片岡 祐子 他

\section{3:15 14:00 糖代謝 4 /糖尿病治療}

座長 : 犬飼 敏彦(獨協医科大学越谷病院 糖尿病内分泌・血液内科)

P2-079 シタグリプチン新規投与症例の長期予後の検討

太田記念病院 内分泌内科

自治医科大学附属さいたま医療センター 内分泌代謝科 齊藤 智之 他

P2-080 選択的 SGLT2 阻害薬ルセオグリフロジンの長期的臨床効果

公立松任石川中央病院 糖尿病内分泌内科 赤堀弘 他

P2-081 DPP-4 阻害薬発売後の低血糖性昏睡 39 例の検討 浜松医療センター 内分泌代謝内科 岡田 美咲 他

P2-082 リナグリプチンの有効性、安全性と腎機能との関連

慶應義塾大学病院 医学部 腎蔵内分泌代謝内科 西村 健志 他

P2-083 ビデュリオン投与中に皮下硬結を認め炎症性偽腫瘍と診断した一例

九州大学大学院 医学研究院 病態制御内科

医療法人 光輝会 平生クリニックセンター 堀内由布子 他

P2-084 デグルデク以外のインスリンに即時型アレルギー反応を認めた一例

浜松医科大学 第二内科 酒井 勇輝 他

\section{4:00 14:45＼cjkstart糖代謝 $5 /$ 脂質・その他}

座長：大門 眞(弘前大学大学院医学研究科 内分泌代謝内科)

P2-085 血中インスリン濃度が測定感度以下であった耐糖能異常の一例

旭川医科大学内科学講座 病態代謝内科分野 藤田 征弘 他

P2-086 aripiprazole 開始後より血糖上昇を呈した新生児糖尿病の一例 旭川医科大学 小児科 松尾公美浩 他

P2-087 HHS に合併した可逆性脳梁膨大部病変を有する軽症脳症の一例

筑波大学附属病院水戸地域医療教育センター・水戸協同病院 内分泌代謝・糖尿病内科 戒能 賢太 他 


\section{3:15～14:00＼cjkstart糖代謝 $6 /$ 低血糖 1}

座長：吉岡 成人(NTT 東日本札幌病院 糖尿病内分泌内科)

P2-088 GHRP2 負荷試験を用いた低血糖症の鑑別

熊本大学大学院 生命科学研究部 代謝内科学 河島 淳司 他

P2-089 低血糖様症状或いは低血糖で紹介された 16 症例の検討

兵庫県立加古川医療センター 総合内科 門田 悠紀 他

P2-090 最近経験した低血糖の 3 症例 玄々堂君津病院 内科荻野 良郎 他

P2-091 重症低血糖患者は副腎不全症または GH 分泌不全症を高率に合併する

独立行政法人 労働者健康福祉機構 東京労災病院 糖尿病 - 内分泌内科 本間 正史 他

P2-092ステロイドにより低血糖を回避しえた肝細胞癌関連 NICTH

金沢赤十字病院 糖尿病・腎センター

金沢大学医薬保健研究域医学系恒常性制御学 寺村 千里 他

P2-093 末期の回腸原発性 GIST に難治性低血糖を合併した 1 例 獨協医科大学越谷病院 櫻井慎太郎 他

P2-094 中枢性尿崩症に膵島細胞症を合併し術後も血糖管理に難渋した 1 例

東京女子医科大学 高血圧 - 内分泌内科 村山 友樹 他

\section{4:00～14:45＼cjkstart糖代謝 7／インスリノーマ 2・低血糖 2}

座長：佐倉 宏(東京女子医科大学 東医療センター 内科)

P2-095 プロインスリンの過剩分泌を認めないインスリノーマの 1 例

医療法人鉄蕉会亀田総合病院 青山 麻織 他

P2-096 術前局在診断に苦慮した $6 \mathrm{~mm}$ 大のインスリノーマの 1 例

湘南藤沢徳洲会病院 内分泌・糖尿病内科 河崎さつき 他

P2-097 てんかん・反応性低血糖との鑑別に難渋したインスリノーマの症例

東京女子医科大学 東医療センター 性差医療部・内科

健成会小林脳神経外科病院 片井みゆき 他

P2-098 診断に難渋した mixed adenoneuroendocrine carcinoma の 1 例

大阪赤十字病院 糖尿病内分泌内科 村上 隆亮 他

P2-099 Diazoxide にて治療中の高インスリン血性低血糖症の 1 例

筑波技術大学 保健管理センター 横田千津子 他

P2-100 新生児症候性低血糖症で脳 MRI 異常所見を一過性に呈した一例

旭川厚生病院 小児科 向井 徳男 他

\section{3:15 14:00 性腺 2}

\section{座長：堂地勉(鹿児島大学大学院 医歯学総合研究科 生殖病態生理学)}

P2-101 高テストステロン血症の原因と考えられた成熟襄胞性奇形腫の一例

中京病院 内分泌・糖尿病内科 川口 頌平 他

P2-102 Degarelix 投与後超急性期の血中ホルモン值変動の検討

獨協医科大学越谷病院 泌尿器科 新井 学 他

P2-103 Aromatase Inhibitor および Dienogest を組み合わせた新しい治療

御茶ノ水・浜田病院 産婦人科 合阪 幸三 他 


\section{4:00 14:45 多発性内分泌腫瘍症}

座長：今井 常夫(愛知医科大学 乳腺・内分泌外科)

P2-104ＭEN 遺伝子イントロン 4 内に変異を認めた MEN 1 型の 1 症例

草津総合病院 糖尿病 - 内分泌内科 嚴西 真規 他

P2-105 複数の臓器病変が同時に明らかとなった MEN1 型への治療アプローチ

国立病院機構 京都医療セン夕一内分泌 - 代謝内科 垣田真以子 他

P2-106 口腔内粘膜神経腫を契機に MEN2B と診断された一例

横浜医療センター 糖尿病内分泌内科 小松裕美子 他

P2-107 慢性下痢症と大腸多発憩室を契機に診断された MEN2B の一例

大阪大学大学院 医学系研究科 小児科学 皆川 光 他

\section{3:15～14:00＼cjkstart骨カルシウム代謝 3／PTHrP 産生腫瘍・副甲状腺癌} 座長：山本 昌弘(島根大学医学部 内科学講座 内科学第一)

P2-108 PTHrP 産生卵巣癌・褐色細胞腫により高 Ca 血症を来した 1 例 長野市民病院 北原順一郎 他

P2-109 PTHrP の産生を認めた膵内分泌腫瘍の 1 例

東京女子医科大学 医学部 高血圧 - 内分泌内科 大槻 昌子 他

P2-110ＰTHrP 産生悪性褐色細胞腫の高 Ca 血症を denosumab で治療した一例

東京女子医科大学 高血压・内分泌内科 鈴木 薰 他

P2-111＼cjkstart高 Ca 制御困難時貧血進行と癌骨髄浸潤を認めた PTHrP 産生腫瘍の 1 例

新潟県厚生農業協同組合連合会 新潟医療センター 糖尿病センター 五十嵐智雄 他

P2-112 抗 RANKL 抗体製剂にて Ca コントロールを行った副甲状腺癌の一例

熊本大学医学部附属病院 代謝 - 内分泌内科 西田 周平 他

\section{4:00〜14:45＼cjkstart骨カルシウム代謝 4／その他}

座長：山口 徹(島根大学医学部 内科学第一)

P2-113 抗ウィルス剤(核酸アナログ)で誘発された低リン血症の 1 症例

愛知医科大学 医学部 内分泌代謝内科 森田 博之 他

P2-114ＦDG-PET が腫瘤同定に有用であった腫瘍性骨軟化症の一例

九州大学大学院医学研究院 病態制御内科学 内田啓一郎 他

P2-115 FGF23 関連低リン血症性疾患患者の FGF23 と心肥大との関係性の検討

東京大学医学部附属病院 腎臓・内分泌内科 高士 祐一 他

P2-116＼cjkstart骨折を契機にミルクアルカリ症候群を呈した一例

愛知県厚生連 安城更生病院 内分泌 - 糖尿病内科 平山 将之 他

\section{3:15 14:00 研修医・学生部門 下垂体 3/尿崩症・下垂体機能低下症・下垂体炎}

座長：村瀬＼cjkstart孝司(国立病院機構名古屋医療センター＼cjkstart糖尿病・内分泌内科)

P2-117中枢性尿崩症と GHD を伴ったランゲルハンス細胞組織球症の一例

国立病院機構 呉医療センター・中国がんセンター 内分泌・糖尿病内科 永田 秀樹 他

P2-118リンパ球性漏斗下垂体後葉炎により中枢性尿崩症を呈した 1 例

高知大学 医学部 卒後臨床研修センター 黒川 早紀 他

P2-119 リンパ球性漏斗下垂体後葉炎による中枢性尿崩症が疑われた一例

埼玉医科大学病院 内分泌内科 - 糖尿病内科 中尾 嘉修 他

P2-120 自律神経失調症として放置されていた下垂体機能低下症の一例

済生会横浜市東部病院 糖尿病 - 内分泌内科 児島 希典 他 
P2-121 分娩後早期に Sheehan 症候群を発症し診断し得た 1 例

北海道大学 医学部 免疫 - 代謝内科学分野澤谷亮佑 他

P2-122＼cjkstart非結核性抗酸菌による下垂体炎が疑われた血液透析患者の 1 例 東京女子医科大学病院 高血圧 - 内分泌内科 岡本 彬美 他

P2-123 高カルシウム血症を契機に診断した IgG4 関連下垂体炎の一例

徳島大学病院卒後臨床研修センター 山下 雄也 他

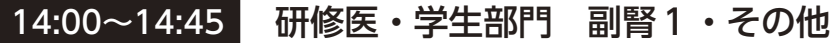

\section{座長：海老原 健 (自治医科大学医学部 内科学講座 内分泌代謝学部門)}

P2-124 結核暴露後 25 年で発症したと考えられる結核性アジソン病の一例

西神戸医療センター 高島 伶奈 他

P2-125 巨大後腹膜神経鞘腫と副腎皮質腺腫の合併が見られた 1 例

高知大学医学部附属病院 卒後臨床研修センター 小笠原佑記 他

P2-126 成人になって診断された Bartter 症候群 2 型の一例

鹿児島大学院 医歯学総合研究科 糖尿病内分泌内科学 新中須 敦 他

P2-127 ビタミン D 欠乏により、SHPT を合併した、重症骨軟化症の一例

兵庫医科大学 内科学 糖尿病 - 内分泌 - 代謝科 森本 晶子 他

P2-128 関節痛を呈し新規遺伝子变異を同定し得た xanthine 尿症 1 型の一例

島根大学 医学部 卒後臨床研修センター 藤澤 遙香 他

P2-129 低身長を契機に診断された isodicentric Yp 染色体を有する 2 例

東京医科歯科大学 発生発達病態学分野 宮川 雄一 他

\section{3:15 14:00 研修医・学生部門 副腎 2/褐色細胞腫・クッシング症候群}

\section{座長：飯野 和美 (JA 静岡厚生連 遠州病院 内分泌内科)}

P2-130 L-dopa 内服下に診断し得た褐色細胞腫の一例

飯田市立病院 渡辺彩 他

P2-131 糖尿病の発症を契機に発見された paragangliomaの一例

$\mathrm{JA}$ 北海道厚生連 札幌厚生病院 糖尿病 - 内分泌内科 推井 大雄 他

P2-132 副腎皮質機能温存を試みた VHL 病に伴う両側褐色細胞腫の手術例

国立病院機構 京都医療センター 内分泌代謝内科 廣嶋 佳歩 他

P2-133 進行する筋強直性ジストロフィーを合併した褐色細胞腫の一例 沼津市立病院 内科熟巣 佳奈 他

P2-134 病理解剖により PPNAD が疑われた一例

社会医療法人 愛仁会高槻病院 糖尿病内分泌内科 飯塚 徳昭 他

P2-135＼cjkstart原発性アルドステロン症とコルチゾール産生腺腫を合併した 1 例

高知大学医学部 卒後臨床研修センター 江田 雅志 他 


\section{MEMO}

